\title{
Kebutuhan Penyuluhan Agroforestri untuk Rehabilitasi Lahan di Sumba Timur, Nusa Tenggara Timur, Indonesia
}

Endri Martini, James M. Roshetko, Pratiknyo Purnomosidhi, Gerhard Sebastien 



\section{Kebutuhan Penyuluhan Agroforestri untuk Rehabilitasi Lahan di Sumba Timur, Nusa Tenggara Timur, Indonesia}

Endri Martini, James M Roshetko, Pratiknyo Purnomosidhi, Gerhard Sabastian 


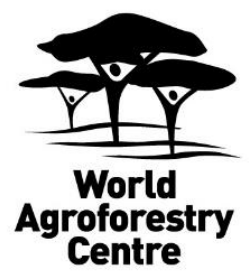

\section{Correct citation:}

Martini E, Roshetko JM, Purnomosidhi P, Sabastian G. 2016. Kebutuhan Penyuluhan Agroforestri untuk Rehabilitasi Lahan di Sumba Timur, Nusa Tenggara Timur, Indonesia. Working Paper no. 231. Bogor, Indonesia: World Agroforestry Centre (ICRAF) Southeast Asia Regional Program.

DOI: http://dx.doi.org/10.5716/WP16077.PDF

Titles in the Working Paper Series aim to disseminate interim results on agroforestry research and practices and stimulate feedback from the scientific community. Other publication series from the World Agroforestry Centre include: agroforestry perspectives, technical manuals and occasional papers.

Published by the World Agroforestry Centre

ICRAF Southeast Asia Regional Program

JL. CIFOR, Situ Gede, Sindang Barang, Bogor 16680

PO Box 161, Bogor 16001, Indonesia

Tel: +62 2518625415

Fax: +62 2518625416

Email: icraf-indonesia@cgiar.org

ICRAF Southeast Asia website: http://www.worldagroforestry.org/region/southeast-asia/

(C) World Agroforestry Centre 2016

Working Paper 231

\section{Photos: World Agroforestry Centre}

The views expressed in this publication are those of the author(s) and not necessarily those of the World Agroforestry Centre.

Articles appearing in this publication may be quoted or reproduced without charge, provided the source is acknowledged.

All images remain the sole property of their source and may not be used for any purpose without written permission of the source. 


\section{Tentang Penulis}

Endri Martini saat ini bekerja di World Agroforestry Centre (ICRAF) sebagai peneliti penyuluhan agroforestri sejak tahun 2011. Beliau bergabung dengan ICRAF sejak tahun 2001 dan bekerja dalam berbagai topik agroforestri seperti konservasi keanekaragaman hayati dan pemberdayaan masyarakat. Gelar S1 diperolehnya dari Jurusan Silvikultur di Fakultas Kehutanan, Institut Pertanian Bogor. Gelar S2 bidang Sumber Daya Alam dan Pengelolaan Lingkungan diperolehnya dari University of Hawaii at Manoa, Hawaii, USA.

James M Roshetko adalah peneliti di bidang Sistem Agroforestri yang saat ini juga memiliki posisi sebagai Kepala Unit Trees and Market -World Agroforestry Centre (ICRAF) Asia Tenggara. Beliau memiliki pengalaman kerja 37 tahun, termasuk 19 tahun di Indonesia dan 28 di Asia Tenggara dan Asia Selatan. Saat ini beliau adalah Koordinator Proyek IRED-ICRAF: proyek mengimplementasikan pengetahuan ke aksi. Fokus penelitiannya selama ini adalah sistem pertanian skala kecil yang berbasis pohon sebagai sebuah sistem pengelolaan pertanian dan sumber daya alam berkelanjutan yang berkontribusi secara nyata terhadap pengembangan ekonomi lokal sekaligus pelestarian lingkungan secara global. James menyandang gelar doktor dalam bidang Ilmu Bumi dan Pengelolaan Sumber Daya Alam dari University of Copenhagen, Denmark and gelar master dalam bidang Pengelolaan Hutan dan Agoroforestri dari Michigan State University, USA.

Pratiknyo Purnomosidhi adalah peneliti agroforestri yang bekerja di World Agroforestry Centre (ICRAF) sejak 1993. Perhatiannya meliputi berbagai hal seperti cadangan karbon di atas dan di bawah permukaan tanah dan hidrologi agroforestri di Lampung dan Jambi, serta terlibat dalam berbagai kegiatan pemberdayaan masyarakat dengan fokus pengelolaan agroforestri di Nanggroe Aceh Darussalam dan Sulawesi. Beliau memperoleh gelar master dalam bidang Ilmu Pengelolaan Tanah dan Air dari Universitas Gadjah Mada, Yogyakarta, dan gelar Sarjana Ilmu Tanah diperolehnya dari Universitas Brawijaya, Malang.

Gerhard Sabastian bekerja sebagai peneliti Sistem Agroforestri di World Agroforestry Centre (ICRAF) dengan pengalaman 20 tahun dalam berbagai proyek penelitian dan pengembangan di Indonesia. Saat ini Gerhard adalah Manajer Proyek IRED-ICRAF. Obyek penelitiannya terutama terkait dengan sistem agroforestri petani kecil dengan fokus pengembangan pengelolaan silvikultur pohon dan jenis hasil hutan bukan kayu (HHBK) bagi penguatan ekonomi lokal dan penyediaan jasa lingkungan berkelanjutan. Gerhard mendapatkan gelar doktor bidang Pengelolaan Hutan dari Australian National University dan master dalam bidang Pengelolaan Sumber Daya Alam dari Institut Pertanian Bogor. 


\section{Abstrak}

Tujuan penelitian ini adalah menyediakan informasi dasar tentang kebutuhan penyuluhan agroforestri untuk mendukung tercapainya tujuan-tujuan proyek agroforestri dalam rehabilitasi lahan di Sumba Timur. Hasil penelitian ini diharapkan dapat membantu menerapkan pendekatan agroforestri dalam 23 tahun mendatang, khususnya di Kecamatan Haharu (wilayah dengan kondisi alam paling kritis di Sumba Timur), dan di Kabupaten Sumba Timur pada umumnya. Penelitian ini menggunakan metode Diskusi Kelompok Terfokus (FGD) dengan masyarakat di 3 desa di Kecamatan Haharu (Wunga, Rambangaru dan Kadahang) dan dengan petugas penyuluh di tingkat kecamatan, untuk mengumpulkan informasi tentang kebutuhan penyuluhan agroforestri dan hambatan-hambatan yang dihadapi dalam rehabilitasi lahan di Kecamatan Haharu. Selain itu, wawancara tokoh kunci dilakukan dengan dinas terkait (Dinas Pertanian, Dinas Perkebunan dan Dinas Kehutanan) serta lembaga non pemerintah (Wahana Visi Indonesia, Yayasan Tananua dan Lutheran World Relief), untuk memperoleh masukan mengenai hambatan-hambatan yang dihadapi dalam upaya rehabilitasi lahan di Kecamatan Haharu dan potensi jenis-jenis kegiatan penyuluhan agroforestri yang terkait. Hasil penelitian menunjukkan bahwa hambatan utama terhadap rehabilitasi lahan adalah kurangnya sumber air, rendahnya kesuburan tanah, gangguan ternak, bahaya kebakaran, kurangnya pendampingan untuk memastikan keberlanjutan program penanaman pohon, serta keterbatasan bibit berkualitas. Berdasarkan hambatan-hambatan tersebut, kebutuhan penyuluhan agroforestri diidentifikasi dan dibahas dalam tulisan ini. Sekolah lapang agroforestri merupakan pilihan utama pendekatan penyuluhan yang diusulkan petani untuk meningkatkan pengetahuan dan kapasitas mereka dalam mengelola kebun dan rehabilitasi lahan di Kecamatan Haharu. Diintegrasikan dengan sekolah lapang agroforestri, demplot (kebun contoh) agroforestri diharapkan dapat dibangun dan dikembangkan di setiap kampung dalam 2-3 tahun mendatang sebagai media interaktif untuk belajar tentang praktik agroforestri yang akan bermanfaat bagi rehabilitasi lahan di Haharu. Jenis sistem agroforestri yang dapat dikembangkan dalam demplot ditentukan berdasarkan kombinasi jenis tanaman prioritas dan yang diminati petani. Petugas penyuluhan dan petani harus bekerjasama secara intensif untuk memastikan petani dapat berpartisipasi dan belajar selama proses perencanaan, pembuatan, dan pengelolaan demplot.

Kata kunci: Demplot, Kebun Contoh, Wunga, Rambangaru, Kadahang, Haharu 


\section{Ucapan Terima Kasih}

Penelitian ini didukung oleh Indonesian Rural Economic Development (IRED) Sumba Program yang dilaksanakan oleh Wahana Visi Indonesia (WVI) bekerjasama dengan World Agroforestry Centre (ICRAF) dan Lutheran World Relief (LWR) melalui skema pendanaan Australian Government Department of Foreign Affairs and Trade (DFAT). Kami sampaikan penghargaan atas dukungan dan kontribusi dari masyarakat yang berpartisipasi, organisasi-organisasi non pemerintah dan dinas terkait di Kabupaten Sumba Timur, terutama masyarakat dan para petugas penyuluhan di Kecamatan Haharu, Kabupaten Sumba Timur. Kami juga sampaikan penghargaan atas masukan dan dukungan yang diberikan Tim WVI di Sumba Timur. Dan ucapan terima kasih pada Aunul Fauzi yang sudah membantu menerjemahkan working paper ini dari versi Bahasa Inggris ke versi Bahasa Indonesia. 


\section{Daftar Isi}

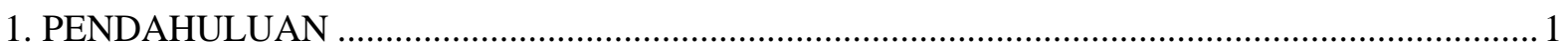

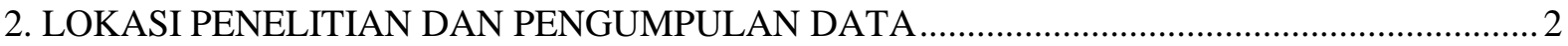

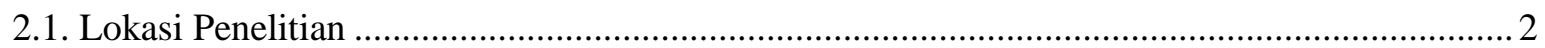

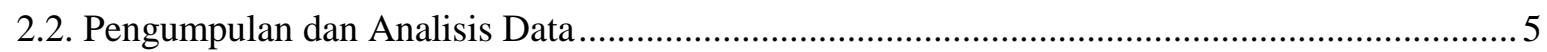

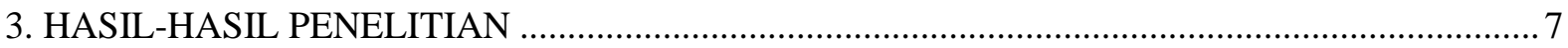

3.1. Program-program terkini dalam penanaman pohon dan pengelolaan regenerasi alami oleh

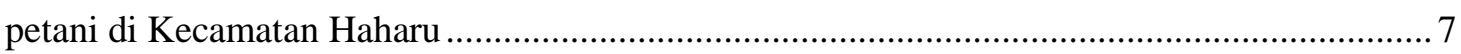

3.1.1. Program-program penanaman pohon.....................................................................

3.1.2. Program pengelolaan regenerasi alami oleh petani ................................................ 13

3.2. Kebutuhan penyuluhan untuk rehabilitasi lahan di Kecamatan Haharu .................................... 14

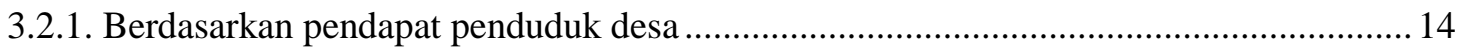

3.2.2. Berdasarkan pendapat petugas penyuluhan pemerintah .......................................... 17

3.3. Potensi program agroforestri untuk rehabilitasi lahan di Kecamatan Haharu .......................... 18

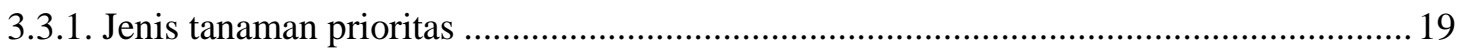

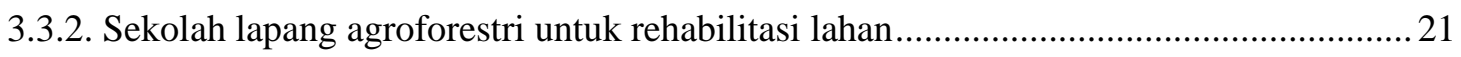

3.3.3. Kebun contoh agroforestri untuk rehabilitasi lahan.................................................... 21

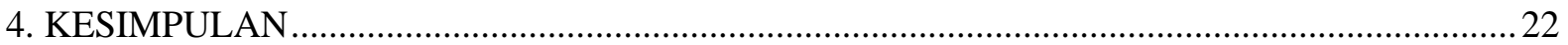

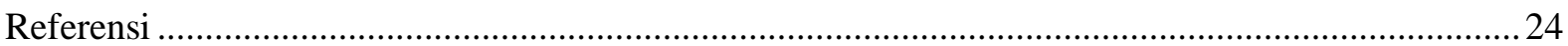




\section{Daftar Tabel}

Tabel 1. Karakteristik desa di Kecamatan Haharu, Kabupaten Sumba Timur ....................................... 4

Tabel 2. Program-program pemerintah dalam penanaman pohon di Kecamatan Haharu ...................... 8

Tabel 3. Program penanaman pohon oleh LSM tahun 2016 di Kecamatan Haharu ............................... 9

Tabel 4. Program penanaman pohon yang diterima masyarakat Wunga, Kadahang dan Rambangaru di Kecamatan Haharu.

Tabel 5. Kecenderungan hambatan-hambatan program penanaman pohon menurut pandangan petani dalam 10-20 tahun terakhir dan 10-20 tahun yang akan datang

Tabel 6. Ketersediaan layanan penyuluhan dari dinas pemerintah dan LSM di Kecamatan Haharu. .. 15

Tabel 7. Kebutuhan layanan penyuluhan dari perspektif petani di Kecamatan Haharu. ...................... 16

Tabel 8. Kebutuhan pelatihan dan penyuluhan bagi penyuluh di Kecamatan Haharu......................... 18

Tabel 9. Jenis pohon yang banyak dan tumbuh baik di Kecamatan Haharu........................................ 19

Tabel 10. Jenis tanaman yang diprioritaskan untuk ditanam oleh petani di Kecamatan Haharu..........20

Tabel 11. Kebun contoh (demplot) yang direkomendasikan petugas penyuluhan...............................22

\section{Daftar Gambar}

Gambar 1. Peta lokasi penelitian di Sumba Timur, Nusa Tenggara Timur. ........................................... 3

Gambar 2. Curah hujan di Kecamatan Haharu dari tahun 2008 sampai 2014 ..................................... 4

Gambar 3. Total produksi tanaman pertanian di Kecamatan Haharu dari tahun 2009 sampai 2014

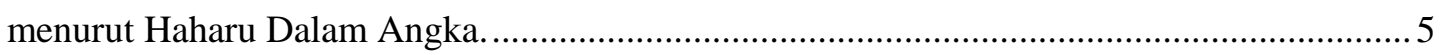

Gambar 4. Total jumlah hewan ternak di Kecamatan Haharu dari tahun 2009 sampai 2014 menurut

Haharu Dalam Angka.

Gambar 5. Pola curah hujan rata-rata tahunan di setiap desa berdasarkan diskusi dengan penduduk desa di Wunga, Kadahang dan Rambangaru, Kecamatan Haharu. ............................................ 6

Gambar 6. Sketsa Desa Wunga, Kecamatan Haharu, Sumba Timur .....................................................26

Gambar 7. Sketsa Desa Kadahang, Kecamatan Haharu, Sumba Timur ….........................................26

Gambar 8. Sketsa Desa Rambangaru, Kecamatan Haharu, Sumba Timur ...........................................2 27 
Daftar Jenis Tumbuhan

\begin{tabular}{llll}
\hline Nama Indonesia & $\begin{array}{l}\text { Jenis Pohon } \\
\text { (English) }\end{array}$ & $\begin{array}{l}\text { Nama Lokal } \\
\text { (Sumba) }\end{array}$ & Nama Botani \\
\hline Bakau & Mangrove tree & Bakau & Sonneratia spp. \\
\hline Johar & Cassia tree & Johar & Senna siamea \\
\hline Kedondong pagar & Indian ash tree & Kehi & Lannea coromandelica \\
\hline Salam & Indonesian bay-leaf & Lobung & Syzygium polyanthum \\
\hline Kesambi & Lac tree & Kosambi & Scheilechera oleosa \\
\hline Lontar & Borassus & Minggit/Tuak & Borassus flabellifer \\
\hline Kelapa & Coconut & Kelapa & Cocos nucifera \\
\hline Jati putih & Gmelina & Jati putih & Gmelina arborea \\
\hline Jati & Teak & Jati & Tectona grandis \\
\hline Mahoni & Mahagony & Mahoni & Swietenia mahagony \\
\hline Pinang & Betel nut & Pinang & Areca catechu \\
\hline Sirih & Piper & Sirih & Piper betle \\
\hline Mente & Cashew & Mente & Anacardium occidentale \\
\hline Kedondong & Hog plum & Kedondong & Spondias dulcis \\
\hline Cendana & Sandalwood & Cendana & Santalum album \\
\hline Kepuh & Java olive tree & Kelumpang & Sterculia foetida \\
\hline Sukun & Breadfruit & Sukun & Artocarpus altilis \\
\hline Nangka & Jackfruit & Nangka & Artocarpus heterophyllus \\
\hline & Injuwatu & Pleiogynium timoriense \\
\hline & Marujawa & \\
\hline
\end{tabular}




\section{PENDAHULUAN}

Nusa Tenggara Timur (NTT) adalah provinsi paling tenggara di Indonesia. NTT, bersama provinsiprovinsi tetangganya, Nusa Tenggara Barat (NTB) dan Maluku, mengalami kondisi ekologi yang tidak biasa bila dibandingkan dengan sebagian besar wilayah Indonesia pada umumnya. Provinsi ini terdiri dari pulau-pulau kecil, memiliki jumlah penduduk terbatas, terisolasi dari daerah lain di Indonesia, dan mengalami musim kemarau lebih panjang. Ini sangat kontras dengan kondisi tropis dan lembab di tempat-tempat lain yang lebih dikenal di Indonesia seperti pulau-pulau besar Sumatera, Jawa, Kalimantan Bali, Sulawesi dan Papua (Roshetko dan Mulawarman, 2002).

Pulau-pulau kecil di Indonesia bagian tenggara menghadapi banyak masalah ekologi dan lingkungan. Rentan terhadap bencana alam: letusan gunung berapi, gempa bumi, tanah longsor dan badai. Wilayah pesisirnya jauh lebih luas dibanding wilayah daratan. Jarak dengan laut berpengaruh langsung terhadap iklim pulau. Daerah Aliran Sungai (DAS)-nya sempit dan memiliki air tanah yang terbatas. Alamnya tergolong khusus dan memiliki banyak spesies unik. Wilayah daratannya terjal dan memiliki tingkat erosi tanah yang tinggi. Sistem penggunaan lahan masih asli, disesuaikan dengan kondisi ekologi dan sosial ekonomi setempat. Ada bahaya degradasi lahan akibat penggunaan lahan secara berlebihan pada lahan yang miskin (Stubenvoll, 2000; Monk et al. 1997).

Pulau Sumba adalah satu dari empat pulau besar di NTT yang terbagi menjadi Kabupaten Sumba Barat, Sumba Timur, Sumba Tengah, dan Sumba Barat Daya. Kondisi Kabupaten Sumba Timur sangat kritis dengan $86 \%$ total wilayah tergolong kritis, yaitu 191.454 ha lahan hutan milik negara dan 411.495 ha bukan hutan (Kementerian Kehutanan Indonesia, 2002). Hutan-hutan dan kebun-kebun dibakar setiap tahun. Sebagian besar tutupan lahan adalah padang rumput, dipertahankan sebagai tempat merumput hewan ternak dengan cara dibakar setiap tahun. Penduduk Sumba Timur sangat miskin dengan pendapatan rumah tangga per tahun sebesar Rp 8.236.127 pada 2013, dan sebanyak 29\% rumah tangga berada di bawah garis kemiskinan (dengan pendapatan bulanan di bawah Rp 260.247) (BPS, 2015). Ketahanan pangan keluarga tidak dapat dipastikan. Ada keinginan masyarakat dan pemerintah untuk melakukan rehabilitasi lahan melalui pertanian berbasis pohon sebagai alternatif diversifikasi sistemsistem pertanian, memperkuat ketahanan pangan, memperbanyak mata pencaharian, meningkatkan konservasi tanah dan air, dan meyediakan jasa lingkungan lainnya. Namun, kondisi lingkungan yang parah mempersulit keberhasilan program-program rehabilitasi lahan di Sumba Timur.

Secara umum terdapat dua pendekatan rehabilitasi lahan, yaitu dengan penanaman pohon dan pengelolaan regenerasi alami oleh petani. Penanaman pohon adalah pendekatan umum yang dilakukan banyak lembaga. Walaupun biayanya lebih tinggi dibandingkan dengan regenerasi alami, pembentukan dan pertumbuhan pohon bisa dipercepat dengan program penanaman. Regenerasi alami memang lebih murah, tetapi pengalaman membuktikan diperlukan waktu panjang untuk menghasilkan dampak yang sama. Yang terbaik adalah menggabungkan kedua pendekatan tersebut. Di Sumba Timur, kedua pendekatan ini telah diterapkan. Namun, perlu kajian dan evaluasi lebih dalam untuk mengetahui kapan masing-masing pendekatan cocok dan bagaimana keduanya diterapkan secara sinergis. Dalam 30 tahun terakhir, program penanaman pohon telah dilaksanakan oleh berbagai pihak untuk merehabilitasi lahan 
kritis di provinsi Nusa Tenggara Timur (termasuk Sumba Timur), namun tingkat keberhasilannya masih rendah karena berbagai hambatan-hambatan yang ditemui dalam pelaksanaannya (Hutabarat, 2006). Sistem agroforestri diusulkan sebagai salah satu sistem pemanfaatan lahan yang diharapkan dapat mendukung keberhasilan program rehabilitasi (Njurumana, 2008; Njurumana dan Prasetyo, 2010), seperti dalam IRED Program (Indonesia Rural Economic Development) Sumba Program.

IRED Sumba Program dimulai sejak tahun 2015 dibawah koordinasi Wahana Visi Indonesia dengan dukungan pendanaan dari Australian Government Department of Foreign Affairs and Trade (DFAT). World Agroforestry Centre (ICRAF) dan Lutheran World Relief (LWR) turut membantu implementasi program. Target IRED adalah memberikan manfaat langsung kepada 3.000 petani dan juga secara tidak langsung kepada lebih dari 10.000 anggota masyarakat NTT. Program ini memanfaatkan agroforestri untuk memperbaiki lahan penggembalaan seluas 5.000 hektar dan mendorong peningkatan produktivitas (Gambaran Proyek IRED, 2015). Dalam Proyek IRED, keefektifan penanaman pohon terhadap peningkatan ketahanan pangan, mata pencaharian, dan jasa lingkungan didorong melalui pengembangan pembibitan masyarakat dan kebun contoh (demplot). Pendekatan dan kegiatan penyuluhan agroforestri dilaksanakan untuk mencapai target-target proyek.

Di Sumba Timur, akses petani terhadap teknologi dan pengelolaan lahan pertanian serta pasar sangat terbatas. Pengetahuan para penyuluh pertanian di tingkat kabupaten tentang sistem pertanian berbasis pohon dan jasa lingkungan juga terbatas. Maka dari itu, penelitian ini dilakukan untuk memberikan informasi dasar mengenai kebutuhan-kebutuhan penyuluhan agroforestri dalam mendukung tercapainya tujuan-tujuan proyek agroforestri untuk rehabilitasi lahan di Sumba Timur. Hasil penelitian ini diharapkan dapat bermanfaat dalam pemenuhan kebutuhan-kebutuhan tersebut dalam 2-3 tahun ke depan, khususnya di Kecamatan Haharu, dan di Kabupaten Sumba Timur pada umumnya.

\section{LOKASI PENELITIAN DAN PENGUMPULAN DATA}

\subsection{Lokasi Penelitian}

Penelitian ini dilakukan di Kecamatan Haharu yang terletak di bagian utara Kabupaten Sumba Timur, Provinsi Nusa Tenggara Timur (Gambar 1). Luas wilayah Kecamatan Haharu adalah 88.090 ha, terbagi menjadi 7 desa dengan jumlah penduduk tahun 2015 sebanyak 6.166 jiwa (10 jiwa/ $/ \mathrm{km}^{2}$ ) atau 2,5\% dari keseluruhan populasi Kabupaten Sumba Timur. Haharu dikenal sebagai wilayah yang lebih kritis dibandingkan dengan kecamatan lainnya. Diukur dengan tipe iklim Schmidt-Ferguson, Haharu bertipe E atau setengah kering dengan tutupan lahan savana / padang rumput. 


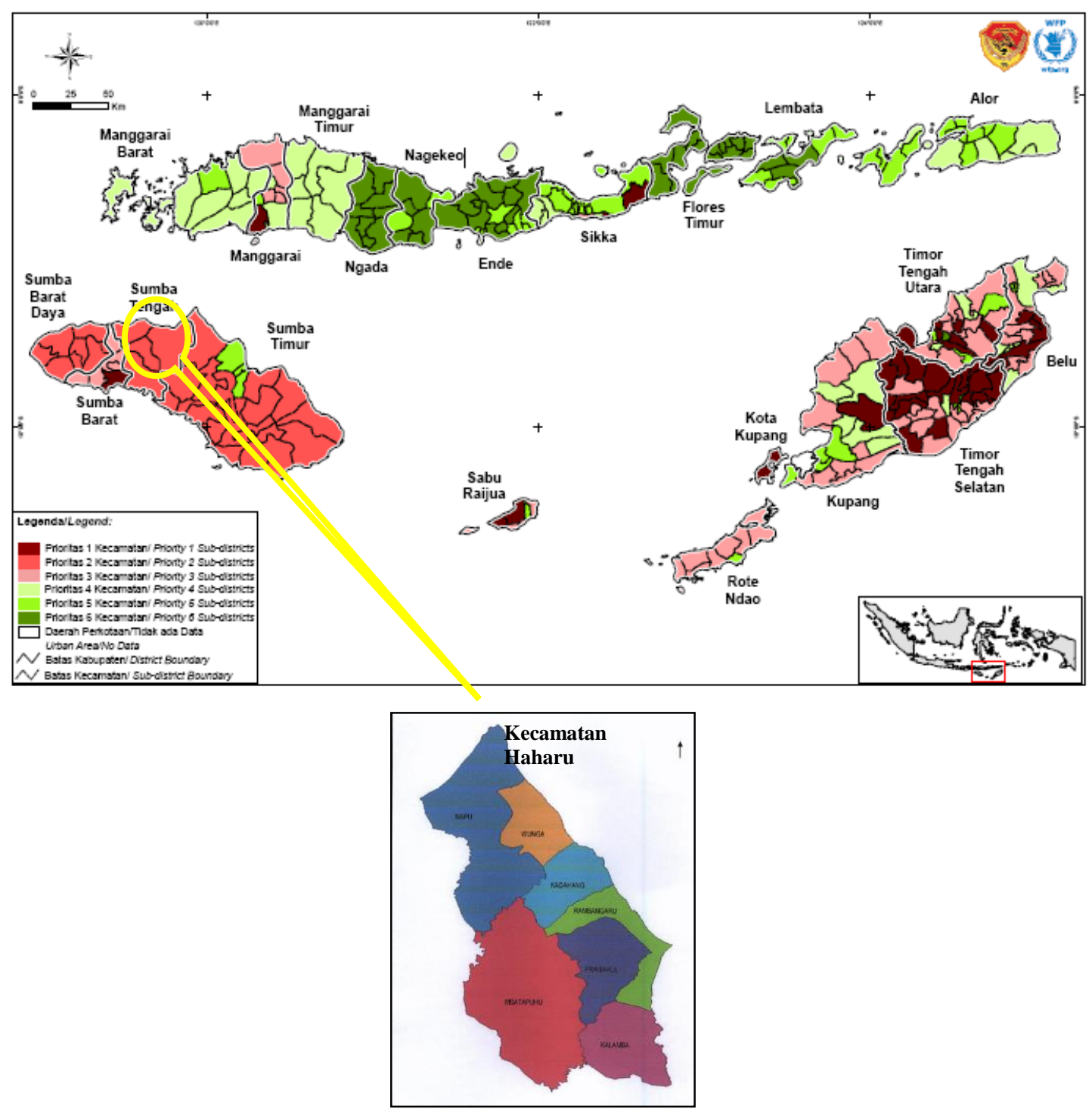

Sumber: Atlas Ketahanan dan Kerentanan Pangan Nusa Tenggara Timur (2010) dan Haharu Dalam Angka (2014).

Gambar 1. Peta lokasi penelitian di Sumba Timur, Nusa Tenggara Timur.

Curah hujan di Kecamatan Haharu dianggap rendah, yaitu sekitar $1000 \mathrm{~mm}$ per tahun dengan hanya 4 bulan basah (Desember-Maret) (Gambar 2.). Karakteristik tanah didominasi batu kapur dan dataran bergelombang dengan ketinggian mulai nol sampai sekitar $320 \mathrm{~m}$ di atas permukaan laut. Air tersedia tak merata di semua desa. Air sangat terbatas, terutama di desa-desa yang terletak dekat laut yaitu Wunga, Kadahang, Praibakul dan Kalamba. Sementara itu, Rambangaru, Napu, dan Mbatapuhu relatif punya air cukup. 


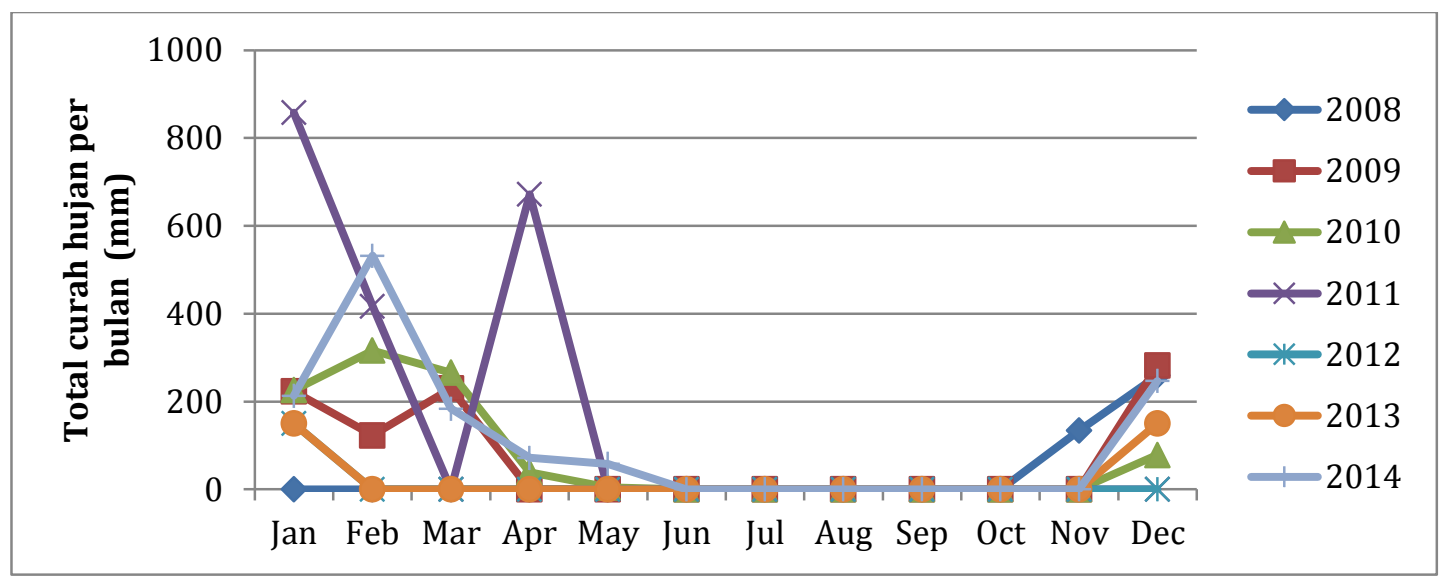

Sumber: Kecamatan Haharu Dalam Angka dari tahun 2008 sampai 2014.

Gambar 2. Curah hujan di Kecamatan Haharu dari tahun 2008 sampai 2014.

Mata pencaharian utama masyarakat Haharu adalah pertanian (83\%), diikuti ternak (9\%) dan memancing (8\%)(Tabel 1.). Suku Sumba adalah etnis dominan di wilayah ini, dan Bahasa Sumba digunakan sebagai bahasa utama, diikuti Bahasa Indonesia. Rata-rata tingkat pendidikan di Kecamatan Haharu adalah sekolah dasar. Hutan di wilayah kecamatan ini terutama terletak di Desa Napu dengan luas 3.375 ha sebagai hutan produksi dan 14.231 ha sebagai hutan lindung.

Tabel 1. Karakteristik desa di Kecamatan Haharu, Kabupaten Sumba Timur

\begin{tabular}{|c|c|c|c|c|c|c|c|}
\hline \multirow[b]{2}{*}{ Desa } & \multirow[b]{2}{*}{$\begin{array}{l}\text { Luas } \\
\text { (Ha) }\end{array}$} & \multirow[b]{2}{*}{$\begin{array}{l}\text { Ketinggian } \\
\text { (m dpl) }\end{array}$} & \multirow{2}{*}{$\begin{array}{l}\text { Jumlah } \\
\text { Mata } \\
\text { Air }\end{array}$} & \multirow{2}{*}{$\begin{array}{l}\text { Total } \\
\text { Rumah } \\
\text { Tangga } \\
\text { (RT) }\end{array}$} & \multicolumn{3}{|c|}{ Persentase dari total RT (\%) } \\
\hline & & & & & Petani & Nelayan & $\begin{array}{l}\text { Peternak } \\
\text { Ternak }\end{array}$ \\
\hline Rambangaru & 6140 & 18 & 4 & 350 & 67,9 & 11,1 & 15,3 \\
\hline PraiBakul & 10500 & 79 & 3 & 216 & 91,7 & 1,6 & 4,0 \\
\hline Mbatapuhu & 21240 & 375 & 4 & 270 & 90,3 & 0,0 & 8,1 \\
\hline Kadahang & 2350 & 234 & 2 & 173 & 75,2 & 13,8 & 9,9 \\
\hline Wunga & 2240 & 207 & 1 & 219 & 85,5 & 2,9 & 9,4 \\
\hline Napu & 14260 & 20 & 4 & 209 & 78,4 & 11,4 & 8,1 \\
\hline Kalamba & 3420 & 227 & 3 & 88 & 89,6 & 0,0 & 9,0 \\
\hline
\end{tabular}

Sumber: Kecamatan Haharu Dalam Angka, 2014

Menurut Haharu Dalam Angka 2014, kacang tanah, ubi kayu, ubi jalar, jagung, beras dan kacang hijau adalah tanaman pangan jangka pendek yang memberikan kontribusi terhadap kehidupan masyarakat Haharu (Gambar 3.). Total produksi tanaman pangan 2009-2014 masih dianggap rendah karena luas daerah yang ditanam masih sedikit, meskipun produktivitasnya dianggap setingkat atau bahkan lebih tinggi dari rata-rata produktivitas kabupaten, terutama untuk kacang, ubi kayu dan ubi kentang. Total luas lahan untuk tanaman pangan di Kecamatan Haharu lebih kecil dibandingkan kecamatan lainnya di Kabupaten Sumba Timur. Ayam, kambing, babi, ternak, kuda dan kerbau adalah hewan ternak yang umum dipelihara dan berkontribusi terhadap kehidupan masyarakat. Ayam memiliki populasi terbesar (Gambar 4.). 


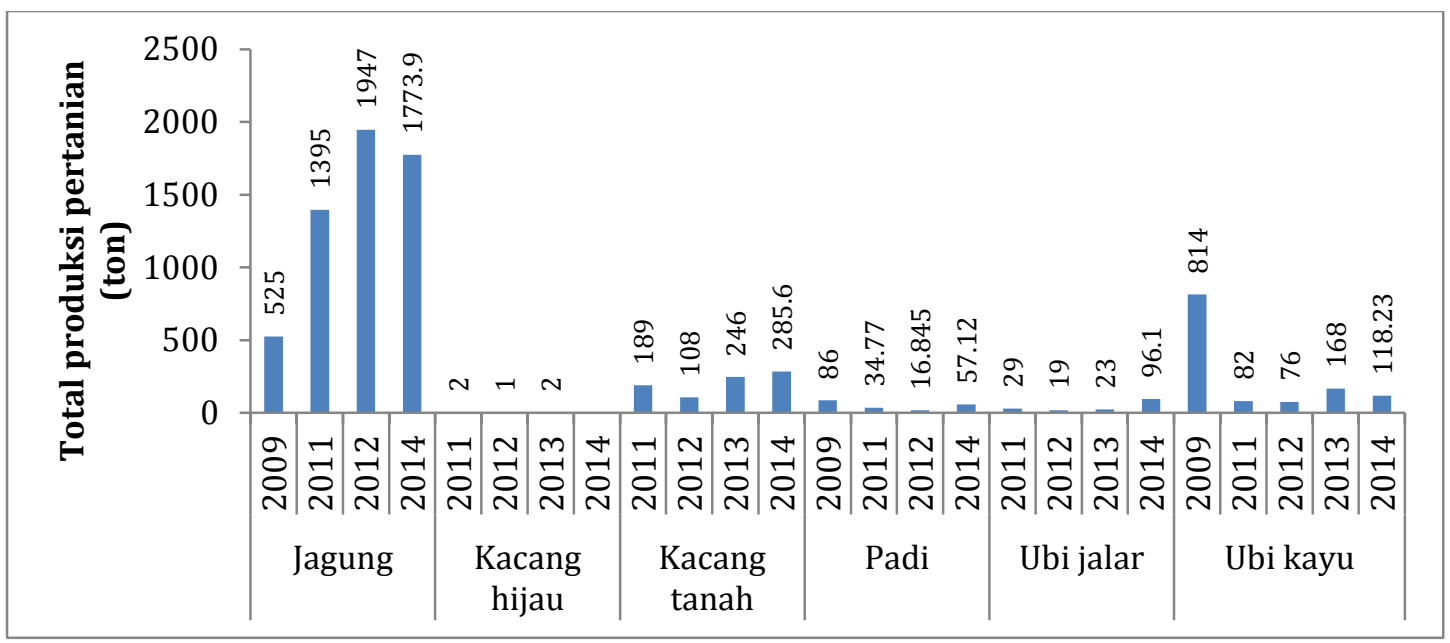

Gambar 3. Total produksi tanaman pertanian di Kecamatan Haharu dari tahun 2009 sampai 2014 menurut Haharu Dalam Angka.

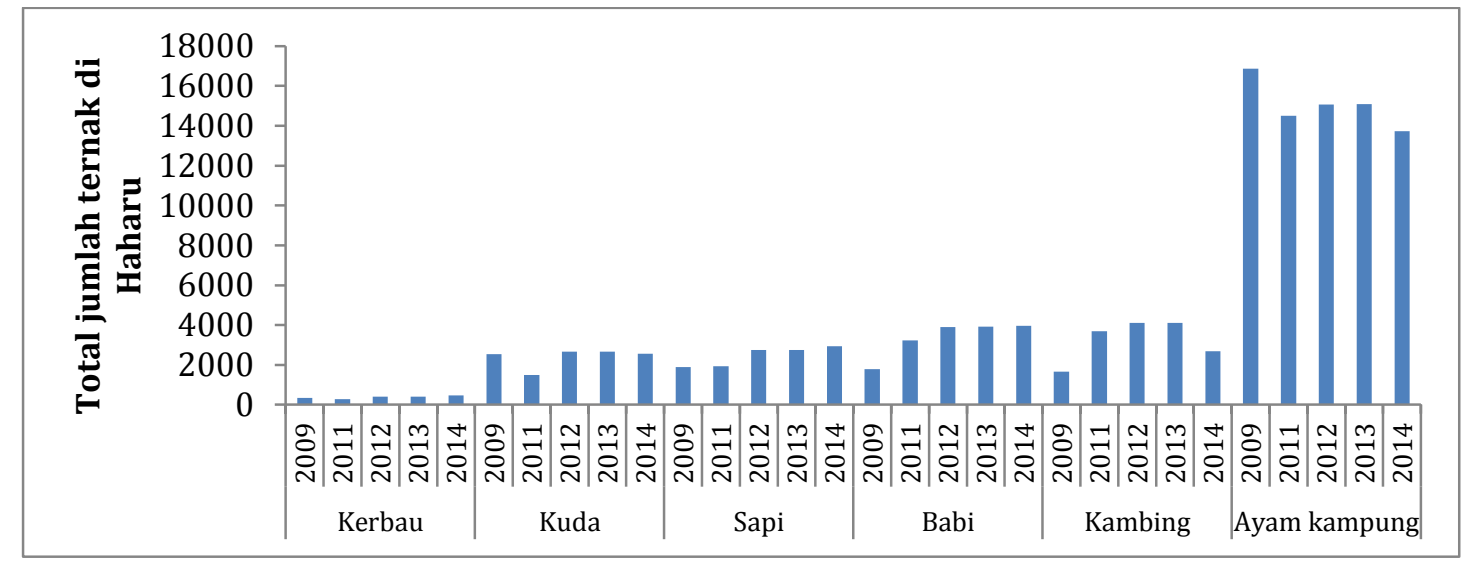

Gambar 4. Total jumlah hewan ternak di Kecamatan Haharu dari tahun 2009 sampai 2014 menurut Haharu Dalam Angka.

\subsection{Pengumpulan dan Analisis Data}

Penelitian dilakukan mulai tanggal 6 hingga 14 April 2016 dengan fokus Kecamatan Haharu tempat Proyek IRED dilaksanakan. Informasi dikumpulkan mengenai kegiatan penyuluhan pertanian yang sudah pernah dilakukan sebelumnya dan yang diharapkan untuk diadakan terkait program penanaman pohon di Kecamatan Haharu. Begitu pula informasi tentang program-program penanaman pohon yang ada serta hambatan-hambatan yang ditemui di Kabupaten Sumba Timur. Informasi tersebut kemudian dianalisis secara kualitatif dan kuantitatif menggunakan statistik deskriptif.

Informasi dikumpulkan melalui:

(i) Tiga Diskusi Kelompok Terfokus (FGD) dengan masyarakat di tingkat desa dan satu FGD dengan penyuluh pemerintah di tingkat kecamatan. FGD di tingkat masyarakat dilakukan dengan melibatkan 8-12 peserta (campuran perempuan dan laki-laki) di 3 dari 7 desa Proyek IRED. Desa dipilih berdasarkan perbedaan akses masyarakat terhadap air (Gambar 5.) yang berperan terhadap keberhasilan program penanaman pohon, yaitu: 
- Wunga, diklasifikasikan sebagai desa dengan akses air terbatas, yaitu punya 1 mata air.

- Kadahang, diklasifikasikan sebagai desa dengan akses air sedang, yaitu punya 2 mata air.

- Rambangaru, diklasifikasikan sebagai desa dengan akses air bagus, punya 4 mata air.

FGD dengan penyuluh di tingkat kecamatan dilakukan dengan mengundang seluruh penyuluh yang bekerja di Kecamatan Haharu (10 orang).

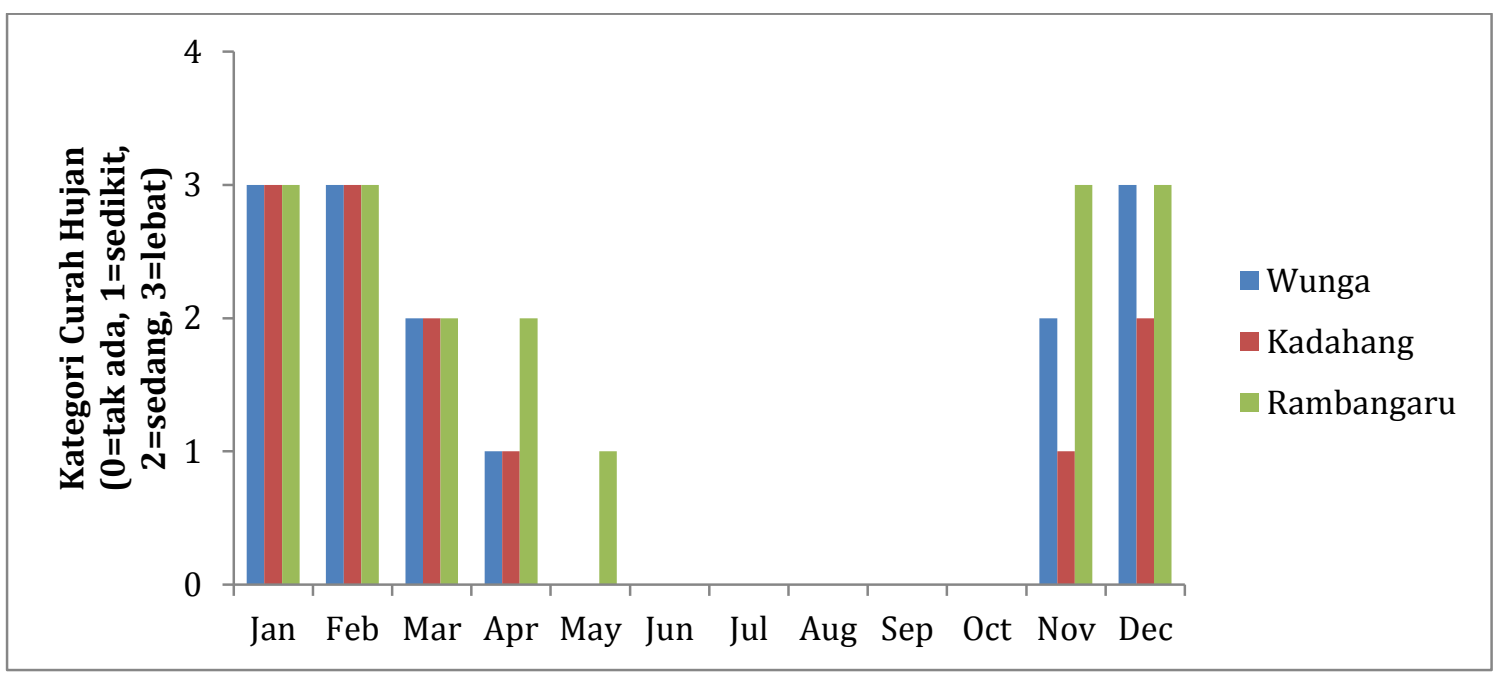

Gambar 5. Pola curah hujan rata-rata tahunan di setiap desa berdasarkan diskusi dengan penduduk desa di Wunga, Kadahang dan Rambangaru, Kecamatan Haharu.

(ii) Wawancara dengan tokoh kunci melalui metode snowball untuk memahami tantangan dan peluang penanaman pohon dan regenerasi alami yang dikelola petani di Sumba Timur. Pemangku kepentingan utama yang dimaksud adalah:

- Dinas Pertanian Kabupaten Sumba Timur (mengumpulkan informasi tentang program penanaman pohon (pohon buah-buahan) yang dikelola oleh Dinas).

- Dinas Kehutanan dan Dinas Perkebunan Kabupaten Sumba Timur (mengumpulkan informasi tentang program Dinas yang terkait dengan penanaman pohon).

- Badan Penyelenggaraan Penyuluhan Pertanian dan Kehutanan Kabupaten (BP3K) Sumba Timur (mengumpulkan informasi tentang jumlah tenaga penyuluh, program-program penyuluhan yang dilaksanakan, dan program peningkatan kapasitas tenaga penyuluh terkait dengan penanaman pohon).

- Wahana Visi Indonesia (WVI), Lutheran World Relief (LWR), and Yayasan Tananua (mengumpulkan informasi tentang implementasi program penanaman pohon dan pengelolaan regenerasi alami oleh petani, kemajuannya, tantangan yang dihadapi, dan potensi kegiatan yang dapat dilakukan terkait upaya peningkatan kapasitas).

(iii) Informasi statistik tentang demografi, produksi pertanian, dan sumber daya hutan di Kabupaten Sumba Timur diperoleh dari Badan Pusat Statistik Kabupaten (BPS). 
(iv) Data sekunder tentang jenis tumbuhan prioritas di Kecamatan Haharu diperoleh dari survei yang dilakukan ICRAF bulan Januari 2016. Sedangkan untuk kebutuhan penyuluhan pertanian pada tingkat rumah tangga diperoleh dari survei rumah tangga oleh WVI pada 2016.

\section{HASIL-HASIL PENELITIAN}

\subsection{Program-program terkini dalam penanaman pohon dan pengelolaan regenerasi alami oleh petani di Kecamatan Haharu}

\subsubsection{Program-program penanaman pohon}

\subsubsection{Program-program pemerintah tentang penanaman pohon}

Di Kecamatan Haharu terdapat 4 dinas pemerintah tingkat kabupaten yang terlibat dalam pelaksanaan program penanaman pohon, yaitu Dinas Pertanian, Dinas Kehutanan, Dinas Perkebunan dan Badan Penyelenggaraan Penyuluhan Pertanian dan Kehutanan. Masing-masing dinas memiliki peran dan program khusus terkait penanaman pohon (Tabel 2.). Berdasarkan diskusi dengan tokoh-tokoh kunci di masing-masing dinas, hambatan-hambatan pelaksanaan program penanaman pohon bervariasi antar instansi. Hambatan-hambatan utama adalah keterbatasan air, gangguan ternak ternak, bahaya api, terbatasnya ketersediaan bibit kualitas baik, kepemilikan tanah, dan kurangnya pendampingan untuk memastikan keberlanjutan program penanaman pohon.

Dinas Pertanian tingkat kabupaten saat ini sedang mengembangkan pertanian kebun pekarangan sebagai bagian dari program rehabilitasi lahan mereka karena cara ini dianggap paling cocok untuk daerah dengan masalah keterbatasan air dan gangguan ternak. Jika dibandingkan dengan Dinas lainnya, Dinas Pertanian mengakui keterbatasan bibit berkualitas sebagai salah satu hambatan program penanaman pohon. Saat ini bibit-bibit buah berkualitas sering didatangkan dari pulau lain seperti jeruk dari Soe (di Pulau Timor). Tantangan utama pengembangan pusat bibit berkualitas di Sumba Timur adalah keterbatasan sumber air dan pohon induk yang berkualitas, serta kurangnya prioritas pemerintah daerah.

Program penanaman pohon yang dikelola Dinas Kehutanan mendorong upaya pembentukan hutan rakyat di lahan-lahan milik pribadi. Tujuan program hutan rakyat adalah penghijauan atau reboisasi lahan pribadi. Dinas Kehutanan menyediakan biji, polibek, pipa air, dan penampungan air ukuran kecil. Para petani hanya perlu membuat kelompok agar dapat mengikuti program ini. Cendana, kayu putih, sengon adalah jenis pohon utama dalam program ini. Program hutan rakyat juga memiliki tujuan untuk perlindungan mata air dan sumur.

Program penanaman pohon dari Dinas Perkebunan difokuskan di bagian selatan Sumba Timur, yaitu di Kecamatan Pinupaharu, Tabundung, dan Ponggaludu yang memiliki kondisi biofisik lebih tepat untuk pengembangan mente, kelapa, pinang, dan sirih. Mente dianggap memiliki nilai ekonomi yang tinggi dibandingkan dengan jenis tanaman lainnya, sehingga setiap tahun ada program untuk ekspansi 
perkebunan mente dan pelatihan penanganan pascapanen bekerjasama dengan Dinas Perindustrian dan Perdagangan kabupaten.

Tabel 2. Program-program pemerintah dalam penanaman pohon di Kecamatan Haharu

\begin{tabular}{|c|c|c|c|}
\hline $\begin{array}{l}\text { Dinas } \\
\text { Pemerintah }\end{array}$ & $\begin{array}{l}\text { Peran dalam program } \\
\text { penanaman pohon }\end{array}$ & $\begin{array}{l}\text { Program penanaman pohon pada } \\
\text { tahun } 2016\end{array}$ & $\begin{array}{l}\text { Hambatan terhadap } \\
\text { program penanaman }\end{array}$ \\
\hline $\begin{array}{l}\text { Dinas Pertanian } \\
\text { Kabupaten }\end{array}$ & $\begin{array}{l}\text { Mengembangkan dan } \\
\text { menyelenggarakan } \\
\text { program penanaman } \\
\text { pohon buah dengan tujuan } \\
\text { ketahanan pangan }\end{array}$ & $\begin{array}{l}\text { Program tanan pohon di pekarangan } \\
\text { dengan sistem tumpangsari kacang } \\
\text { tanah dan jagung di bawah pohon } \\
\text { mangga, jeruk dan rambutan. }\end{array}$ & $\begin{array}{l}\text { 1. Keterbatasan air } \\
\text { 2. Gangguan ternak } \\
\text { 3. Kekurangan bibit } \\
\text { tanaman buah dari } \\
\text { pohon induk berkualitas }\end{array}$ \\
\hline $\begin{array}{l}\text { Dinas Kehutanan } \\
\text { Kabupaten }\end{array}$ & $\begin{array}{l}\text { Mengembangkan dan } \\
\text { menyelenggarakan } \\
\text { program penanaman } \\
\text { pohon untuk rehabilitasi } \\
\text { dan konservasi lahan. }\end{array}$ & $\begin{array}{l}\text { a. Dalam kawasan hutan negara: } \\
\text { penanaman cendana dengan tujuan } \\
\text { meningkatkan populasi cendana } \\
\text { dalam hutan negara; } \\
\text { b. Di luar kawasan hutan negara: } \\
\text { Penanaman cendana dengan skema } \\
\text { Hutan Rakyat; Pembibitan Pohon } \\
\text { Desa (Kebun Bibit Desa / KBD dan } \\
\text { Kebun Bibit Rakyat / KBR) untuk } \\
\text { cendana, mahoni, jati putih, dan } \\
\text { injuwatu. }\end{array}$ & $\begin{array}{l}\text { 1. Gangguan ternak } \\
\text { 2. Api } \\
\text { 3.Keterbatasan air } \\
\text { 4. Isu sosial (isu } \\
\text { kepemilikan lahan) }\end{array}$ \\
\hline $\begin{array}{l}\text { Dinas } \\
\text { Perkebunan } \\
\text { Kabupaten }\end{array}$ & $\begin{array}{l}\text { Mengembangkan dan } \\
\text { menyelenggarakan } \\
\text { program penanaman } \\
\text { tanaman industri berbasis } \\
\text { pohon. }\end{array}$ & $\begin{array}{l}\text { a. Peningkatan produksi mente. } \\
\text { b. Peningkatan produksi kelapa } \\
\text { (untuk dilaksanakan tahun 2017) }\end{array}$ & $\begin{array}{l}\text { 1. Kurangnya } \\
\text { pendampingan untuk } \\
\text { memastikan } \\
\text { keberlanjutan program } \\
\text { penanaman pohon }\end{array}$ \\
\hline $\begin{array}{l}\text { Badan } \\
\text { Penyelenggaraan } \\
\text { Penyuluhan } \\
\text { Kabupaten dan } \\
\text { Kecamatan }\end{array}$ & $\begin{array}{l}\text { Mendukung dan } \\
\text { memfasilitasi program } \\
\text { penanaman pohon yang } \\
\text { diinisiasi oleh Dinas } \\
\text { Pertanian, Dinas } \\
\text { Kehutanan, dan Dinas } \\
\text { Perkebunan. }\end{array}$ & $\begin{array}{l}\text { a. Dinas Pertanian: Program } \\
\text { ketahanan pangan (program } \\
\text { nasional) dan pengembangan kebun } \\
\text { pekarangan (program kabupaten). } \\
\text { b. Dinas Kehutanan: Kebun Bibit } \\
\text { Rakyat (program nasional) dan } \\
\text { Kebun Bibit Desa (program } \\
\text { kabupaten). } \\
\text { c. Dinas Perkebunan: Peningkatan } \\
\text { produksi mente dan kelapa (program } \\
\text { kabupaten dan provinsi). }\end{array}$ & $\begin{array}{l}\text { 1. Gangguan ternak } \\
\text { 2. Keterbatasan air }\end{array}$ \\
\hline
\end{tabular}

Sumber: Wawancara tokoh kunci pada masing-masing dinas pemerintah.

Badan Penyuluhan memiliki peran penting dalam menjamin keberlanjutan kegiatan penanaman pohon melalui pendampingan intensif dan monitoring. Ada sejumlah tantangan yang dihadapi badan penyuluhan, seperti keterbatasan jumlah dan kurangnya kapasitas tenaga penyuluhan. Badan penyuluhan membenarkan perlunya upaya-upaya pelatihan lebih lanjut.

\subsubsection{Program penanaman pohon yang diinisiasi dan dilaksananan lembaga non pemerintah} (LSM)

Di Sumba Timur, ada sejumlah LSM untuk pengembangan masyarakat dalam bidang ketahanan pangan, pengentasan kemiskinan, dan isu-isu lingkungan. Yayasan Tananua adalah yang tertua. 
Yayasan Tananua bermitra dengan berbagai organisasi lain di Sumba Timur, juga di daerah lainnya, seperti Pelita, KOPPESDA, World Neighbours, Kemitraan Indonesia, Yakersum, Yasalti, FALP (Forum Anda Lindu Pala dalam hal pemasaran), YSS (Yayasan Sumba Sejahtera), WVI (Wahana Visi Indonesia), Bumi Lestari, Stimulant, Pahadang Majoru dan instansi pemerintah lainnya. Kolaborasi dengan instansi pemerintah juga dilakukan oleh Yayasan Tananua terutama untuk memperoleh bibit bagi program penanaman pohon. LSM penting lainnya yang saat ini beraktifitas di Kecamatan Haharu adalah Wahana Visi Indonesia (WVI) dengan pengalaman 10 tahun, dan Lutheran World Relief (LWR).

Tabel 3. Program penanaman pohon oleh LSM tahun 2016 di Kecamatan Haharu

\begin{tabular}{|c|c|c|c|}
\hline LSM & $\begin{array}{l}\text { Peran dalan program } \\
\text { penanaman pohon }\end{array}$ & $\begin{array}{l}\text { Program penanaman pohon pada } \\
\text { tahun } 2016\end{array}$ & $\begin{array}{l}\text { Hambatan terhadap } \\
\text { program } \\
\text { penanaman }\end{array}$ \\
\hline $\begin{array}{l}\text { Yayasan } \\
\text { Tananua }\end{array}$ & $\begin{array}{l}\text { Pemberdayaan } \\
\text { masyarakat dan } \\
\text { pelatihan bagi kelompok- } \\
\text { kelompok tani. }\end{array}$ & $\begin{array}{l}\text { a) Kerjasama dengan LWR dalam } \\
\text { Pertanian Cerdas Iklim di Desa Wunga } \\
\text { (Haharu). } \\
\text { b) Kerjasama dengan The Nature } \\
\text { Conservancy (TNC) Indonesia untuk } \\
\text { pemberdayaan masyarakat di Desa } \\
\text { Napu dalam program hutan rakyat. } \\
\text { c. Kerjasama dengan Pelita dan } \\
\text { Koppesda dalam SPARC (Strategic } \\
\text { Planning and Action to Strengthen } \\
\text { Climate Resilience of Rural } \\
\text { Communities) yang bertujuan untuk } \\
\text { memperkuat kemampuan masyarakat } \\
\text { dalam hal ketahanan pangan, sumber } \\
\text { daya air, dan ketahanan penghidupan } \\
\text { dalam menghadapi perubahan iklim. }\end{array}$ & $\begin{array}{l}\text { 1. Keterbatasan air } \\
\text { 2. Gangguan ternak }\end{array}$ \\
\hline $\begin{array}{l}\text { Wahana Visi } \\
\text { Indonesia } \\
\text { (WVI) }\end{array}$ & $\begin{array}{l}\text { Pemberdayaan } \\
\text { masyarakat dan } \\
\text { pelatihan bagi kelompok } \\
\text { tani. }\end{array}$ & $\begin{array}{l}\text { Indonesia Rural Economic } \\
\text { Development (IRED) dengan tujuan } \\
\text { membantu petani meregenerasi lahan } \\
\text { pertanian dan hutan yang sudah } \\
\text { kritis,serta meningkatkan hasil dan } \\
\text { kualitas panen, akses pasar dan } \\
\text { pendapatan. }\end{array}$ & $\begin{array}{l}\text { 1. Gangguan ternak } \\
\text { 2. Api }\end{array}$ \\
\hline $\begin{array}{l}\text { Lutheran } \\
\text { World Relief } \\
\text { (LWR) }\end{array}$ & $\begin{array}{l}\text { Menyediakan bantuan } \\
\text { pembangunan } \\
\text { penampungan air. }\end{array}$ & $\begin{array}{l}\text { a) Indonesia Rural Economic } \\
\text { Development (IRED) } \\
\text { b) Pertanian Cerdas Iklim - Climate } \\
\text { Smart Agriculture }\end{array}$ & 1. Keterbatasan air \\
\hline
\end{tabular}

Sumber: Wawancara dengan tokoh kunci pada masing-masing LSM.

\subsubsection{Program penanamam pohon yang diterima petani dan hambatan-hambatannya}

Di tingkat desa, banyak program penanaman pohon yang sudah dilaksanakan dalam 10 tahun terakhir. Namun, tingkat kelangsungan hidup pohon masih rendah. Berdasarkan diskusi dengan petani, kelangsungan hidup bibit bervariasi mulai $0 \%$ hingga 50\% (Tabel 4.). Tidak ada dokumen yang secara 
sistematis mencatat tingkat kelangsungan hidup bibit-bibit tersebut. Angka-angka yang diberikan petani hanyalah perkiraan berdasarkan persepsi mereka.

Tabel 4. Program penanaman pohon yang diterima masyarakat Wunga, Kadahang dan Rambangaru di Kecamatan Haharu.

\begin{tabular}{|c|c|c|c|c|c|}
\hline Desa & Lembaga & $\begin{array}{l}\text { Program Penanaman } \\
\text { Pohon }\end{array}$ & Tahun & $\begin{array}{l}\text { Jumlah } \\
\text { Pohon } \\
\text { Bertahan } \\
\text { Hidup } \\
\end{array}$ & Catatan \\
\hline \multirow{5}{*}{ Wunga } & CRS-AUSAID & $\begin{array}{l}\text { Program delegasi sosial } \\
\text { untuk mendistribusikan } \\
\text { bibit kemiri, mangga, dan } \\
\text { sukun. }\end{array}$ & 2003 & $50 \%$ & $\begin{array}{l}\text { Beberapa pohon kemiri } \\
\text { yang bertahan hidup } \\
\text { kini sudah berbuah. }\end{array}$ \\
\hline & $\begin{array}{l}\text { Dinas } \\
\text { Kehutanan } \\
\text { provinsi }\end{array}$ & $\begin{array}{l}\text { Pembagian bibit } \\
\text { (1 keluarga = 5-10 bibit). }\end{array}$ & 2006 & $50 \%$ & $\begin{array}{l}\text { Pohon tumbuh dengan } \\
\text { baik. }\end{array}$ \\
\hline & Pidra & $\begin{array}{l}\text { Distribusi bibit mahoni dan } \\
\text { jati putih melalui kelompok } \\
\text { tani. }\end{array}$ & 2007 & $50 \%$ & \\
\hline & WVI & $\begin{array}{l}\text { Demplot dan FMNR, } \\
\text { penanaman cendana, } \\
\text { sukun, mangga. }\end{array}$ & 2010 & $50 \%$ & \\
\hline & $\begin{array}{l}\text { Dinas } \\
\text { Perkebunan } \\
\text { Kabupaten }\end{array}$ & $\begin{array}{l}\text { Perkebunan kelapa dan } \\
\text { kapas }\end{array}$ & $\begin{array}{l}2008 \\
2010\end{array}$ & $0 \%$ & $\begin{array}{l}\text { Kelapa dan kapas } \\
\text { bukan prioritas di } \\
\text { Wunga. Tidak ada } \\
\text { pendampingan. }\end{array}$ \\
\hline \multirow{7}{*}{ Kadahang } & $\begin{array}{l}\text { Dana } \\
\text { Pembanguna } \\
\mathrm{n} \text { Desa }\end{array}$ & $\begin{array}{l}\text { Rehabilitasi lahan dengan } \\
\text { mahoni dan jati putih }\end{array}$ & 2007 & $25 \%$ & \\
\hline & \multirow[t]{2}{*}{$\begin{array}{l}\text { Dinas } \\
\text { Kehutanan } \\
\text { Kabupaten }\end{array}$} & $\begin{array}{l}\text { Program KBD (Kebun Bibit } \\
\text { Desa) dengan mahoni, } \\
\text { dan jati putih, } 50.000 \text { bibit } \\
\text { dibagikan kepada para } \\
\text { petani. }\end{array}$ & 2014 & $30 \%$ & $\begin{array}{l}\text { Bibit sudah dibagikan } \\
\text { dan ditanam. }\end{array}$ \\
\hline & & $\begin{array}{l}\text { Pembagian } 11.000 \text { bibit } \\
\text { untuk konservasi dan } \\
\text { perlindungan mata air. }\end{array}$ & 2014 & $4 \%$ & $\begin{array}{l}\text { Ada sekitar } 400 \text { pohon } \\
\text { yang bertahan hidup. }\end{array}$ \\
\hline & Yayasan & & & & \\
\hline & $\begin{array}{l}\text { Sumba } \\
\text { Sejahtera } \\
\text { (YSS) }\end{array}$ & $\begin{array}{l}\text { Pembagian bibit cendana, } \\
\text { mahoni, dan jati putih. }\end{array}$ & $2011-2014$ & $25 \%$ & $\begin{array}{l}\text { Pohon cendana masih } \\
\text { ada seluas } 1 \text { hektar. }\end{array}$ \\
\hline & WVI & $\begin{array}{l}\text { Demplot dan pembagian } \\
\text { bibit. }\end{array}$ & $2008-2016$ & $25 \%$ & \\
\hline & Pelita Sumba & Pembagian bibit mahoni. & 2016 & $\begin{array}{l}\text { Tidak } \\
\text { tersedia }\end{array}$ & $\begin{array}{l}\text { Program ini baru mulai } \\
\text { awal } 2016 \text {. }\end{array}$ \\
\hline \multirow[b]{2}{*}{ Rambangaru } & WVI & $\begin{array}{l}\text { Pembagian bibit mahoni, } \\
\text { jati putih, dan jati. }\end{array}$ & 2013 & $40 \%$ & \\
\hline & $\begin{array}{l}\text { Dinas } \\
\text { Kehutanan } \\
\text { Kabupaten }\end{array}$ & $\begin{array}{l}\text { KBR yang membagikan } \\
50.000 \text { bibit mahoni, jati } \\
\text { putih, dan sukun. }\end{array}$ & 2014 & $45 \%$ & \\
\hline
\end{tabular}

Sumber: FGD bersama masyarakat di setiap desa. 
Berdasarkan pengamatan di lapangan dan diskusi dengan masyarakat desa, penanaman pohon akan berhasil bila berlokasi dekat mata air, sungai, pantai dan di tanah datar yang subur. Jenis pohon yang berhasil tumbuh besar di dekat sungai dan di tanah datar yang subur adalah jenis yang memiliki nilai ekonomi (kelapa dan tanaman perkebunan lainnya), sementara yang tumbuh dan bertahan hidup di sekitar mata air adalah jenis tumbuhan dengan nilai ekonomi yang rendah tetapi bernilai tinggi untuk melindungi mata air.

Rendahnya tingkat kelangsungan hidup pohon-pohon yang ditanam pada dasarnya terkait dengan beberapa permasalahan selama dan sesudah program penanaman. Berdasarkan diskusi dengan penduduk desa, kebakaran merupakan hambatan utama, terutama di Kadahang dan Rambangaru. Yang kedua adalah gangguan ternak, dan yang ketiga keterbatasan sumber air. Hama dan penyakit tanaman adalah yang keempat dan kesuburan tanah menjadi hambatan yang kelima. Di Rambangaru, terbatasnya ketersediaan bibit berkualitas juga merupakan hambatan utama dalam program penanaman pohon. Di Kadahang, sumber daya manusia juga menjadi hambatan utama, khususnya karena terbatasnya pengetahuan masyarakat tentang pengelolaan pemeliharaan ternak dan pengendalian kebakaran. Perlu dilaksanakan pelatihan untuk meningkatkan pemahaman para petani tentang penggembalaan ternak dan pengendalian bahaya api.

Kebakaran biasanya terjadi pada musim kemarau. Penyebab utama kebakaran adalah kecerobohan manusia saat membakar sampah dan membuang puntung rokok. Penyebab lain adalah kebiasaan penduduk setempat membakar padang rumput kering untuk merangsang pertumbuhan rumput baru yang menjadi pakan ternak yang digembala. Saat ini tidak ada aturan bagaimana sebaiknya cara membakar padang gembalaan untuk meremajakan rumput. Namun, dalam beberapa tahun belakangan, sudah ada upaya pendidikan dan sosialisasi cara mengendalikan api yang terbukti cukup efektif mengurangi terjadinya kebakaran padang.

Gangguan ternak biasanya terjadi karena ternak dibiarkan berkeliaran bebas mencari rumput. Sementara itu, pemilik tidak mengawasi kemana dan dimana ternaknya berada. Kebun dibiarkan tidak berpagar. Juga tidak adanya aturan desa tentang pemisahan wilayah tempat merumput dengan kebun. Di Kecamatan Haharu, di Desa Kalamba telah mulai dikembangkan peraturan desa untuk membedakan lahan penggembalaan dan kebun. Gangguan ternak ini terjadi di semua desa di Kecamatan Haharu.

Keterbatasan sumber daya air juga merupakan faktor utama penyebab rendahnya tingkat kelangsungan hidup pohon yang ditanam. Di beberapa lokasi seperti Wunga, kekurangan air merupakan hal yang selalu terjadi. Tetapi di daerah lain seperti di Kadahang dan Rambangaru, masalah keterbatasan air mulai dirasakan dalam 10 tahun terakhir ini. Petani merasa saat ini kekeringan menjadi lebih sering terjadi di Haharu karena penggundulan hutan akibat penebangan liar dan pembakaran padang gembalaan yang terjadi setiap tahun.

Sumber air pada masing-masing desa di Kecamatan Haharu beragam. Ada yang mengandalkan air hujan dan mata air, sungai dan atau sumur. Saat ini di Wunga, masyarakat menerima bantuan dari pemerintah dan organisasi lain seperti LWR dan Tananua untuk membangun penampungan air kecil dengan ukuran bervariasi mulai dari $2 \times 2$ sampai $4 \times 4$ meter persegi. 
Musim kemarau di Haharu biasanya terjadi pada bulan Mei hingga Oktober. Pada musim kemarau, sumber air bagi keperluan rumah tangga biasanya adalah mata air, sumur, atau mengambil air dari desa lain. Sebagian masyarakat bahkan mungkin membeli air. Di Rambangaru dan Kadahang yang terletak di dekat sungai, petani menanam sepanjang bantaran sungai ketika kemarau. Sementara itu di Wunga, petani biasanya menghentikan kegiatan pertanian selama musim kemarau. Selama musim kemarau, ternak mencari minum di desa-desa sekitar atau di sungai. Kadang, banyak ternak mati karena kekurangan air dan makanan.

Dalam lima tahun terakhir, serangan hama dan penyakit tanaman dan ternak terus meningkat. Menurut petani, hal itu terjadi akibat kekeringan yang menyebabkan tanaman dan ternak stres dan menjadi rentan terhadap hama dan penyakit. Namun, beberapa petani lainnya, seperti di Kadahang, mengatakan tidak tahu apa yang menyebabkan terjadinya serangan hama dan penyakit. Saat ini jenis tumbuhan yang paling umum diserang hama adalah jati putih, kelapa, bakau, dan kosambi. Biasanya batang dan daun kosambi diserang serangga putih pada bulan Mei. Hama ini muncul dalam 5 tahun terakhir. Sementara, penyakit yang umum terjadi pada ternak adalah demam pada babi, kembung pada kambing, lumpuh pada sapi, dan flu pada ayam.

Jenis tanah di Haharu bervariasi untuk masing-masing desa, tergantung lokasi. Desa-desa yang terletak dekat pantai (Wunga, Napu, sebagian Kadahang, dan sebagian Rambangaru), cenderung memiliki tanah berkapur. Petani tidak tahu bagaimana cara meningkatkan kesuburan tanah kapur sehingga usaha pertanian di daerah-daerah tersebut rentan gagal pada tahun-tahun kekeringan. Desa-desa yang terletak di areal yang berbukit seperti Kalamba dan Mbatapuhu cenderung memiliki tanah lebih tebal, berwarna gelap, dan lebih subur.

Berdasarkan pengalaman selama 10-20 tahun terakhir, sebagian besar petani merasa bahwa 10-20 tahun berikutnya kondisi akan lebih baik dalam hal ketahanan pangan, kontrol api dan tutupan lahan (Tabel 5.). Namun, mereka merasa masalah sumber daya air dan gangguan ternak tidak akan lebih baik dalam 10-20 tahun ke depan, terutama jika tidak ada bantuan untuk mencari cara mengatasi masalah-masalah tersebut. Dengan demikian, bantuan atau penyuluhan terkait sumber daya air dan pengelolaan ternak merupakan komponen penting untuk meningkatkan keberhasilan program penanaman pohon di Haharu. Menurut petani, mereka belum pernah menerima manfaat ekonomi langsung dari penanaman pohon, karena pohon-pohon yang mereka tanam dan berhasil tumbuh saat ini masih muda (kurang dari 10 tahun). Namun, mereka berharap mendapatkan keuntungan dalam 20-30 tahun mendatang dalam bentuk: (i) peningkatan pendapatan keluarga; (ii) tersedianya kayu untuk digunakan sendiri; dan (iii) penjualan kayu. Selain manfaat ekonomi, mereka juga berharap memperoleh manfaat lingkungan seperti suhu yang lebih sejuk, lingkungan yang nyaman, dan berkurangnya masalah kekeringan. 
Tabel 5. Kecenderungan hambatan-hambatan program penanaman pohon menurut pandangan petani dalam 10-20 tahun terakhir dan 10-20 tahun yang akan datang

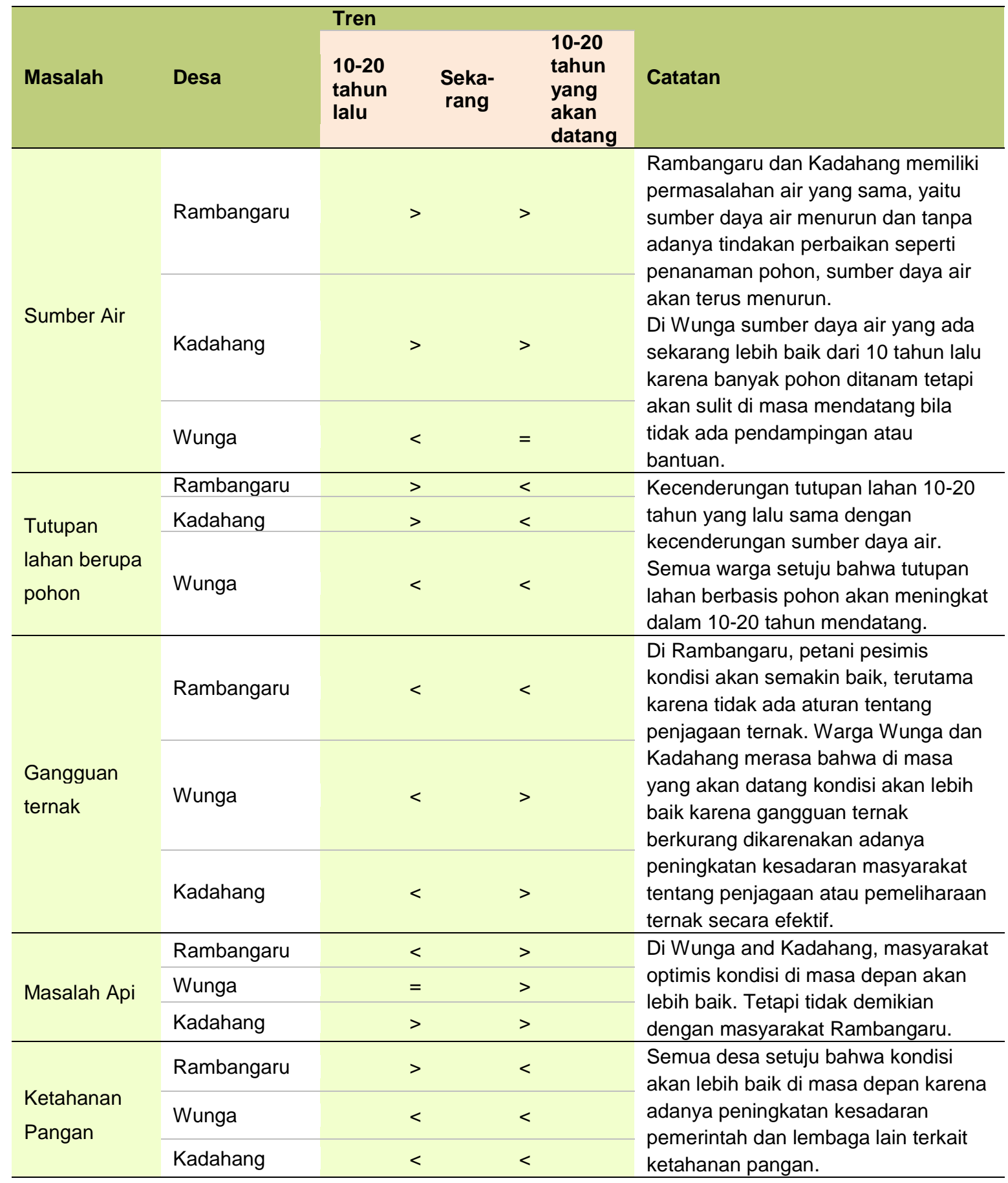

Sumber: FGD di tingkat desa

\subsubsection{Program pengelolaan regenerasi alami oleh petani}

Pengelolaan regenarasi alami oleh petani (Farmers Managed Natural Regeneration, FMNR) adalah teknik restorasi lahan untuk meningkatkan produksi pangan dan kayu, meliputi regenerasi sistematis dan pengelolaan pohon dan semak-semak tunggul pohon, akar dan biji (Rinaudo, 2012). Di Kecamatan Haharu, WVI memperkenalkan FMNR melalui program INFOCUS (Increase Food Security within the Community through Sustainable Livelihood and Natural Resource Management System) yang bertujuan 
untuk memotivasi petani agar menanam dan memelihara pohon di lahan mereka. Gangguan ternak dan bahaya kebakaran adalah hambatan dalam pelaksanaan FMNR di Haharu. FMNR juga dikenal sebagai "palotang" dalam Bahasa Sumba.

Dalam program palotang, petani dilatih mengelola pohon agar tumbuh sehat dengan pemangkasan dan penjarangan. Petani diminta memangkas pohon setiap bulan. Satu keluarga diminta menjaga 600 pohon. Petani menentukan lokasi palotang mereka di daerah dengan gangguan ternak atau ancaman kebakaran sedikit. Pohon yang mereka rawat diberi tanda dengan tali dan dipantau setiap bulan.

Saat ini petani masih memiliki beberapa lokasi palotang dengan pohon-pohon yang sudah dipangkas dan dijarangkan. Mereka juga masih memantau pertumbuhan pohon di lokasi palotang sebelumnya. Berdasarkan diskusi dengan petani, pohon yang sudah dipalotang tumbuh dengan baik namun sebagian besar pohon yang dipangkas merupakan jenis tumbuhan dengan nilai ekonomi rendah, sehingga mereka belum merasakan manfaat finansial langsung dari program palotang. Mereka hanya memperoleh manfaat berupa pengetahuan tentang pemeliharaan pohon. Ke depannya, petani akan menerapkan pengetahuannya yang mereka peroleh melalui kegiatan palotang, di kebunnya sendiri.

\subsection{Kebutuhan penyuluhan untuk rehabilitasi lahan di Kecamatan Haharu}

\subsubsection{Berdasarkan pendapat penduduk desa}

Berdasarkan diskusi dengan penduduk desa, berbagai kegiatan penyuluhan sudah dilakukan oleh banyak lembaga meliputi bidang kehutanan, pertanian, perikanan dan pengelolaan ternak (Tabel 6.). Pelatihan agroforestri sudah dilakukan WVI di semua desa. Penyuluhan oleh pemerintah hanya teridentifikasi di Kadahang dan Rambangaru, sementara penyuluhan yang dilakukan oleh pihak swasta dan LSM menjangkau semua desa di Kecamatan Haharu. Hal ini menunjukkan pentingnya peran penyuluh lembaga non pemerintah di Kecamatan Haharu.

Berdasarkan penelitian yang dilakukan di tingkat rumah tangga oleh WVI pada tahun 2016, topik umum agroforestri menempati urutan ketiga yang paling diminati oleh petani di Kecamatan Haharu. Topik pertanian di urutan pertama dan pemeliharaan ternak kedua. Partisipasi petani dalam mengikuti penyuluhan masih terbatas karena tidak ada informasi yang sampai ke petani, tidak ada undangan, dan lokasi pelatihan jauh dari domisili petani. Jenis media penyuluhan yang paling banyak diterima petani adalah leaflet, kemudian booklet dan film. 
Tabel 6. Ketersediaan layanan penyuluhan dari dinas pemerintah dan LSM di Kecamatan Haharu.

\begin{tabular}{|c|c|c|c|c|c|}
\hline Desa & $\begin{array}{l}\text { Dinas } \\
\text { Pemberi } \\
\text { Penyuluhan } \\
\end{array}$ & Topik penyuluhan & $\begin{array}{l}\text { Frekuensi } \\
\text { kunjungan } \\
\text { per tahun }\end{array}$ & $\begin{array}{l}\text { Metode } \\
\text { penyuluhan }\end{array}$ & $\begin{array}{l}\text { Media } \\
\text { penyuluh } \\
\text { an }\end{array}$ \\
\hline \multicolumn{6}{|c|}{ Tenaga penyuluh pemerintah (BP3K) } \\
\hline Kadahang & $\begin{array}{l}\text { Penyuluh } \\
\text { peternakan }\end{array}$ & $\begin{array}{l}\text { Pemeliharaan / } \\
\text { pengelolaan ternak } \\
\text { (kambing, sapi, dan babi). }\end{array}$ & 1 & Diskusi & Tidak ada \\
\hline $\begin{array}{l}\text { Rambangaru, } \\
\text { Kadahang }\end{array}$ & $\begin{array}{l}\text { Penyuluih } \\
\text { kehutanan }\end{array}$ & $\begin{array}{l}\text { Pertemuan dengan } \\
\text { kelompok petani } \\
\text { kehutanan; regulasi } \\
\text { kehutanan. }\end{array}$ & $\begin{array}{l}\text { Kadang- } \\
\text { kadang }\end{array}$ & Diskusi & $\begin{array}{l}\text { Nonton } \\
\text { film }\end{array}$ \\
\hline $\begin{array}{l}\text { Rambangaru, } \\
\text { Kadahang }\end{array}$ & $\begin{array}{l}\text { Penyuluh } \\
\text { perikanan }\end{array}$ & $\begin{array}{l}\text { Konservasi laut dan } \\
\text { pantai; penangkapan ikan } \\
\text { ramah lingkungan; } \\
\text { konservasi terumbu } \\
\text { karang; penanaman } \\
\text { bakau. }\end{array}$ & 1 & $\begin{array}{l}\text { Diskusi } \\
\text { (sosialisasi) }\end{array}$ & Leaflet \\
\hline Rambangaru & $\begin{array}{l}\text { Penyuluh } \\
\text { pertanian }\end{array}$ & $\begin{array}{l}\text { Penanganan hama dan } \\
\text { penyakit pada jagung dan } \\
\text { kacang. }\end{array}$ & 1 & Diskusi & Leaflet \\
\hline \multicolumn{6}{|c|}{ Penyuluhan oleh LSM } \\
\hline Rambangaru & Bethesda & Penanaman pohon. & 4 & Diskusi & Tidak ada \\
\hline Rambangaru & Gereja & Rehabilitasi lahan. & 4 & $\begin{array}{l}\text { Diskusi } \\
\text { (sosialisasi) }\end{array}$ & Tidak ada \\
\hline Rambangaru & ICRAF-IRED & Pembibitan pohon. & 24 & $\begin{array}{l}\text { Pelatihan } \\
\text { dan diskusi }\end{array}$ & Booklet \\
\hline Wunga & Tananua & $\begin{array}{l}\text { Pembibitan; Produksi dan } \\
\text { penggunaan pupuk } \\
\text { organik. }\end{array}$ & 12 & Pelatihan & Booklet \\
\hline Wunga & $\begin{array}{l}\text { LWR dan } \\
\text { Tananua }\end{array}$ & $\begin{array}{l}\text { Membangun } \\
\text { penampungan air hujan. }\end{array}$ & 12 & Diskusi & Tidak ada \\
\hline Kadahang & Pelita Sumba & $\begin{array}{l}\text { Penanaman pohon; } \\
\text { konservasi air dan tanah. }\end{array}$ & 48 & $\begin{array}{l}\text { Diskusi dan } \\
\text { pelatihan }\end{array}$ & Poster \\
\hline $\begin{array}{l}\text { Rambangaru, } \\
\text { Wunga, } \\
\text { Kadahang }\end{array}$ & WVI & $\begin{array}{l}\text { Penanaman pohon; } \\
\text { FMNR; demplot; } \\
\text { Agroforestri. }\end{array}$ & 12 & $\begin{array}{l}\text { Diskusi dan } \\
\text { pelatihan }\end{array}$ & Booklet \\
\hline
\end{tabular}

Sumber: FGD dengan masyarakat

Sebagian besar petani menganggap penyuluhan masih kurang terutama tentang teknologi baru yang dibutuhkan petani. Identifikasi kebutuhan penyuluhan dilakukan melalui dua pendekatan (Tabel 7.). Pertama dengan bertanya langsung tentang topik apa yang ingin mereka pelajari. Kedua dengan mengevaluasi kebutuhan petani berdasarkan analisis terhadap strategi pencaharian mereka selama musim kemarau. Analisis strategi pencaharian petani selama musim kemarau sangat penting karena pada saat kekeringan, rawan pangan, dan peluang pendapatan terbatas, banyak kesempatan muncul. 
Tabel 7. Kebutuhan layanan penyuluhan dari perspektif petani di Kecamatan Haharu.

\begin{tabular}{|c|c|c|}
\hline Pelajaran & Desa & Topik \\
\hline \multirow{3}{*}{$\begin{array}{l}\text { Pertanian } \\
\text { tanah kering }\end{array}$} & \multirow{3}{*}{ Wunga } & Penyiapan lahan \\
\hline & & Penggunaan bibit unggul untuk merestorasi lahan kering \\
\hline & & $\begin{array}{l}\text { Pengendalian hama dan penyakit dalam pengelolaan lahan } \\
\text { kering }\end{array}$ \\
\hline \multirow{5}{*}{ Perikanan } & Rambangaru & Regulasi dan sosialisasi teknologi penangkapan ikan \\
\hline & \multirow[b]{2}{*}{ Kadahang } & Alat dan teknologi untuk meningkatkan produksi perikanan \\
\hline & & $\begin{array}{l}\text { Pemasaran ikan (menjual ikan, keterampilan tawar-menawar, } \\
\text { akses terhadap informasi harga) }\end{array}$ \\
\hline & \multirow{2}{*}{ All villages } & Pemrosesan pascapanen dan pemasaran ikan \\
\hline & & Teknologi dan keterampilan penangkapan ikan \\
\hline \multirow{13}{*}{ Agroforestri } & \multirow{4}{*}{ Wunga } & Pemasaran produk agroforestri \\
\hline & & Persiapan penanaman pohon \\
\hline & & Pengaturan jarak tanam dan penanaman \\
\hline & & Budidaya mente, mangga, sukun dan kemiri \\
\hline & $\begin{array}{l}\text { Wunga, } \\
\text { Rambangaru }\end{array}$ & $\begin{array}{l}\text { Pengendalian hama dan penyakit, terutama untuk kelapa dan } \\
\text { tanaman perkebunan lainnya. }\end{array}$ \\
\hline & \multirow{2}{*}{ Rambangaru } & Pemeliharaan pohon \\
\hline & & Identifikasi pohon induk dan produksi bibit unggul \\
\hline & \multirow{3}{*}{ Kadahang } & Manajemen bera \\
\hline & & Irigasi tetes \\
\hline & & Perbanyakan vegetatif \\
\hline & \multirow{3}{*}{ All villages } & $\begin{array}{l}\text { Identifikasi jenis pohon dengan nilai ekonomi tinggi dan } \\
\text { mencocokkan kondisi biofisik di Haharu. }\end{array}$ \\
\hline & & $\begin{array}{l}\text { Manajemen pembibitan (termasuk pemupukan, persemaian } \\
\text { benih, dan persiapan bibit untuk ditanam di lahan). }\end{array}$ \\
\hline & & $\begin{array}{l}\text { Sosialisasi aturan pemanfaatan hutan untuk menghentikan } \\
\text { penebangan pohon ilegal dan pembakaran lahan. }\end{array}$ \\
\hline \multirow{5}{*}{ Pertanian } & Wunga & $\begin{array}{l}\text { Memfasilitasi hubungan antara kelompok tani dan pemerintah } \\
\text { daerah, khususnya untuk mendorong keterlibatan kelompok } \\
\text { tani dalam program pemerintah. }\end{array}$ \\
\hline & \multirow{2}{*}{ Kadahang } & Irigasi tetes \\
\hline & & Pemanfaatan dan manajemen pupuk kimia dan organik \\
\hline & \multirow{2}{*}{$\begin{array}{l}\text { Kadahang, } \\
\text { Rambangaru }\end{array}$} & Produksi benih jagung, pengendalian hama dan penyakit \\
\hline & & Irigasi sayuran dan jagung selama musim kering \\
\hline \multirow{4}{*}{$\begin{array}{l}\text { Pengelolaan } \\
\text { ternak }\end{array}$} & \multirow{2}{*}{ Kadahang } & Manajemen unggas dan ternak \\
\hline & & Pemasaran ternak \\
\hline & $\begin{array}{l}\text { Kadahang, } \\
\text { Wunga, } \\
\text { Rambangaru }\end{array}$ & $\begin{array}{l}\text { Penanganan hama dan penyakit ternak (ini terutama sejak } \\
\text { adanya peningkatan penyakit demam pada babi, kembung } \\
\text { pada kambing, sapi lumpuh, dan flu pada ayam) }\end{array}$ \\
\hline & $\begin{array}{l}\text { Kadahang, } \\
\text { Rambangaru }\end{array}$ & Nutrisi ternak; sanitasi ternak \\
\hline
\end{tabular}

Sumber: FGD dengan penduduk desa 


\subsubsection{Berdasarkan pendapat petugas penyuluhan pemerintah}

Ada 10 orang penyuluh di Balai Penyuluhan Pertanian, Perikanan dan Kehutanan Kecamatan Haharu (BP3K Haharu). Satu orang penyuluh kehutanan, 1 penyuluh perikanan, 1 penyuluh perkebunan, 3 penyuluh pertanian, dan 3 penyuluh peternakan. Rata-rata lama bertugas di Haharu adalah 5 tahun, bervariasi antara 1 sampai 15 tahun. Tingkat pendidikan tertinggi adalah sarjana (S1).

Diskusi bersama petani adalah metode penyuluhan yang paling umum digunakan oleh penyuluh BP3K di Haharu. Metode lain seperti kunjungan lapangan, demplot, atau pelatihan jarang digunakan karena keterbatasan anggaran. Kendala lain yang dihadapi penyuluh adalah keterbatasan pelatihan, pengalaman, dan kurangnya kesempatan mengikuti kegiatan pengembangan kapasitas. Media penyuluhan yang paling banyak dibagikan penyuluh kepada para petani adalah leaflet. Kadang-kadang poster yang dibuat instansi pemerintah terkait.

Peran utama penyuluh dalam program penanaman pohon adalah sebagai fasilitator program yang diprakarsai oleh lembaga lain seperti dari Dinas Kehutanan atau Dinas Perkebunan di tingkat kabupaten. Penyuluh bertanggung jawab memantau dan membantu pelaksanaan program-program penanaman pohon dari instansi pemerintah lainnya. Berdasarkan pengalaman petugas penyuluhan, program yang banyak berhasil adalah yang diminta oleh petani dan menggunakan jenis tanaman bernilai ekonomi tinggi, seperti program perkebunan mente dan kelapa dari Dinas Perkebunan.

Dari proses diskusi dengan penyuluh, diketahui bahwa dalam memfasilitasi program penanaman pohon di Kecamatan Haharu, hambatan paling besar adalah yang bersifat biofisik seperti kondisi tanah, iklim dan sumber daya air, topografi dan api. Hambatan sosial juga ditemui, khususnya yang berkaitan dengan pengaturan penggembalaan dan pengendalian kebakaran. Dari semua hambatan di atas, masalah kondisi tanah dianggap lebih mudah dan lebih cepat diatasi, yaitu dengan menggunakan pupuk organik dan kompoa untuk memperbaiki kesuburan. Masalah penggembalaan dan bahaya api juga dapat diatasi dengan mengembangkan dan menerapkan peraturan desa atau kabupaten. Hambatan terkait iklim dan sumber daya air merupakan yang tersulit dan perlu waktu lebih lama untuk menyelesaikannya. Dengan demikian, kebutuhan penyuluhan jangka pendek bagi petani adalah penguatan pengetahuan tentang manipulasi kesuburan tanah menggunakan pupuk organik, dan bagi masyarakat adalah pengembangan dan penerapan aturan penggembalaan dan penanggulangan bahaya api.

Penyuluh merasa bahwa pengetahuan dan kapasitas mereka perlu ditingkatkan supaya mampu memberikan penyuluhan yang lebih baik kepada masyarakat. Daftar kebutuhan pelatihan dan penyuluhan bagi penyuluh di Kecamatan Haharu yang teridentifikasi dalam survei dijabarkan dalam Tabel 8. Pembibitan pohon dan produksi pupuk organik adalah topik-topik yang terkait langsung dengan penerapan sistem agroforestri untuk merestorasi lahan. 
Tabel 8. Kebutuhan pelatihan dan penyuluhan bagi penyuluh di Kecamatan Haharu.

\begin{tabular}{|c|c|}
\hline Pelajaran & Topik pelatihan atau penyuluhan \\
\hline \multirow{4}{*}{ Kehutanan } & a) Pembibitan pohon hutan \\
\hline & b) Konsep dan aplikasi agroforestri \\
\hline & $\begin{array}{l}\text { c) Hutan rakyat, terutama implementasinya terkait dengan masih lemahnya koordinasi } \\
\text { antara Dinas Kehutanan dan para penyuluh di tingkat kabupaten maupun kecamatan. }\end{array}$ \\
\hline & d) Sosialiasi peraturan baru kehutanan terkait kondisi di Kecamatan Haharu. \\
\hline \multirow{7}{*}{$\begin{array}{l}\text { Pengelolaan } \\
\text { Ternak }\end{array}$} & a) Reproduksi ternak \\
\hline & b) Penanganan hama dan penyakit ternak \\
\hline & c) Nutrisi ternak \\
\hline & d) Penanganan pascapanen \\
\hline & e) Inseminasi buatan \\
\hline & f) Vaksinasi ternak \\
\hline & g) Produksi pupuk kandang dari kotoran ternak \\
\hline \multirow{3}{*}{ Pertanian } & a) Penanganan hama dan penyakit untuk tanaman pangan dan sayuran \\
\hline & b) Demplot pertanian organik \\
\hline & c) Perkiraan produktivitas pertanian \\
\hline \multirow{3}{*}{ Perkebunan } & a) Pembibitan tanaman perkebunan \\
\hline & b) Agroforestri dan potensi keuntungan ekonominya \\
\hline & c) Penanganan pascapanen mente \\
\hline \multirow{3}{*}{ Perikanan } & a) Pembibitan akuakultur \\
\hline & b) Penanganan hama dan penyakit pada akuakultur \\
\hline & c) Teknologi baru akuakultur atau budidaya ikan \\
\hline
\end{tabular}

Sumber: FGD dengan petugas penyuluh di BP3K Kecamatan Haharu.

\subsection{Potensi program agroforestri untuk rehabilitasi lahan di Kecamatan Haharu}

Rata-rata tingkat pendidikan sebagian besar petani di Sumba adalah sekolah dasar. Survei ini menemukan bahwa pendekatan penyuluhan yang paling tepat untuk para petani adalah mengenalkan lebih banyak teknologi praktis melalui kebun percobaan dan kunjungan lapangan ke petani-petani sukses. Kedua pendekatan ini dapat diimplementasikan melalui sekolah lapang agroforestri, seperti yang pernah dilakukan oleh Martini et al. (2016) di Sulawesi Selatan dan Tenggara dimana tingkat pendidikan petani pada umumnya adalah sekolah dasar ke bawah. Untuk kasus Sumba Timur, topik utama sekolah lapang agroforestri perlu difokuskan pada rehabilitasi lahan - penanaman pohon dan peningkatan pengelolaan sistem agroforestri.

Langkah pertama dalam merencanakan sekolah lapang agroforestri adalah mengidentifikasi jenis tanaman prioritas di setiap desa - baik jenis pohon maupun jenis tanaman jangka pendek yang bisa ditumpangsarikan dalam sistem agroforestri. Kapasitas dan pengetahuan petani tentang pohon dan sistem pengelolaan perlu ditingkatkan melalui sekolah lapang agroforestri. Setelah kapasitas petani ditingkatkan, langkah berikutnya adalah membangun kebun percobaan agroforestri (demplot). Kebun 
percobaan harus dibangun melalui pendekatan partisipatif dan sukarela dimana petani juga mengambil peran dalam merancang dan menjaga demplot.

\subsubsection{Jenis tanaman prioritas}

Dalam program rehabilitasi lahan, jenis tanaman prioritas dapat diketahui dengan mengamati jenis tanaman yang banyak ditemukan dan tumbuh baik di wilayah yang bersangkutan, serta bertanya kepada petani. Menggunakan tanaman yang diprioritaskan petani akan meningkatkan partisipasi dan motivasi petani dalam memelihara tanaman tersebut. Petani lebih rela menyumbangkan tenaga dan waktu jika terlibat dalam proses seleksi dan mengetahui potensi manfaat jenis tersebut untuk meningkatkan mata pencaharian dan pendapatan mereka.

Berdasarkan diskusi dengan petani, pohon yang banyak ditemukan melimpah di Kecamatan Haharu biasanya memiliki nilai ekonomi rendah, seperti bakau, johar, kehi, lobung (lihat Tabel 9). Namun, petani mengakui bahwa pohon dengan nilai ekonomi rendah tersebut bermanfaat untuk menciptakan lingkungan yang baik.

Tabel 9. Jenis pohon yang banyak dan tumbuh baik di Kecamatan Haharu.

\begin{tabular}{|c|c|c|c|c|}
\hline No. & Jenis Pohon & $\begin{array}{l}\text { Baru } \\
\text { dikenalkan }\end{array}$ & $\begin{array}{l}\text { Nilai } \\
\text { ekonomis }\end{array}$ & Manfaat \\
\hline 1 & $\begin{array}{l}\text { Bakau/Mangrove tree } \\
\text { (Sonneratia sp.) }\end{array}$ & Tidak & Rendah & Konservasi pantai \\
\hline 2 & Johar (Senna siamea) & Tidak & Rendah & Bahan bangunan \\
\hline 3 & $\begin{array}{l}\text { Kehi/KayuCina (Lannea } \\
\text { coromandelica) }\end{array}$ & Tidak & Rendah & $\begin{array}{l}\text { Pagar hidup, kayu bakar, dan bahan } \\
\text { bangunan }\end{array}$ \\
\hline 4 & $\begin{array}{l}\text { Lobung/Salam } \\
\text { (Syzygium polyanthum) }\end{array}$ & Tidak & Rendah & $\begin{array}{l}\text { Konservasi sumber mata air, bahan } \\
\text { bangunan, bumbu, dan obat-obatan. }\end{array}$ \\
\hline 5 & $\begin{array}{l}\text { Injuwatu (Pleiogynium } \\
\text { timoriense) }\end{array}$ & Tidak & Sedang & Papan untuk membangun rumah \\
\hline 6 & $\begin{array}{l}\text { Kosambi (Scheilechera } \\
\text { oleosa) }\end{array}$ & Tidak & Sedang & $\begin{array}{l}\text { Kayu bakar, buah, lak (harga jual USD } \\
1,5 \text { sampai USD 5/kg atau Rp } 20.000 \\
\text { hingga Rp } 67.500 / \mathrm{kg} \text { ) }\end{array}$ \\
\hline 7 & $\begin{array}{l}\text { Minggit/Tuak (Borassus } \\
\text { flabellifer) }\end{array}$ & Tidak & Sedang & $\begin{array}{l}\text { Kerajinan tangan, bagian bunga untuk } \\
\text { pembuatan minuman beralkohol } \\
\text { tradisional, buah untuk pakan ternak. }\end{array}$ \\
\hline 8 & Kelapa (Cocos nucifera) & Tidak & Sedang & $\begin{array}{l}\text { Untuk keperluan rumah atau dijual } \\
\text { dalam bentuk buah segar atau kopra; } \\
\text { papan atau kayu untuk bangunan } \\
\text { rumah, daun untuk atap, sabut untuk } \\
\text { tali, minyak kelapa, dan sapu. }\end{array}$ \\
\hline 9 & $\begin{array}{l}\text { Jati putih (Gmelina } \\
\text { arborea) }\end{array}$ & $\mathrm{Ya}$ & Tinggi & $\begin{array}{l}\text { Bahan bangunan; dan daun untuk } \\
\text { pakan ternak. }\end{array}$ \\
\hline 10 & Jati (Tectona grandis) & $\mathrm{Ya}$ & Tinggi & Kayu untuk membangun rumah \\
\hline 11 & $\begin{array}{l}\text { Mahoni (Swietenia } \\
\text { mahagony) }\end{array}$ & $\mathrm{Ya}$ & Tinggi & Kayu untuk membangun rumah \\
\hline
\end{tabular}

Sumber: FGD dengan petani di Haharu 
Injuwatu dan kosambi adalah dua jenis pohon menarik yang terdapat di daerah ini, tumbuh baik dalam iklim kering di Kecamatan Haharu. Kedua jenis ini memiliki nilai ekonomi; namun, pertumbuhannya sangat lambat dan perlu waktu lama untuk mencapai ukuran dengan nilai ekonomi yang baik. Sementara itu, minggit dan kelapa tumbuh lebih cepat, namun nilai ekonominya lebih rendah dari injuwatu dan kosambi. Karena itu, saat ini petani lebih tertarik dengan jenis tanaman baru yang dapat tumbuh baik dan cepat dengan kondisi alam Haharu serta memiliki nilai ekonomi lebih baik seperti pohon kayu, mente, dan sukun. Pohon kayu untuk persiapan pendapatan jangka panjang, sementara mente, pinang dan sukun diharapkan memberikan pendapatan tahunan pada saat berumur 5-10 tahun setelah penanaman (Tabel 10). Pendapatan jangka pendek bulanan yang bisa diharapkan adalah dari kacang hijau, kacang tanah, bawang merah, bawang putih, tomat, dan jagung.

Tabel 10. Jenis tanaman yang diprioritaskan untuk ditanam oleh petani di Kecamatan Haharu.

\begin{tabular}{|c|c|c|c|c|c|}
\hline \multirow{2}{*}{ Desa } & \multicolumn{5}{|l|}{ Prioritas } \\
\hline & 1 & 2 & 3 & 4 & 5 \\
\hline \multicolumn{6}{|c|}{ Jenis tanaman jangka pendek } \\
\hline Kadahang & Kacang hijau & Kacang tanah & Kacang arab & Semangka & Tomat \\
\hline Kalamba & Kacang tanah & Kacang arab & Bawang merah & Singkong & Terong \\
\hline Mbatapuhu & Bawang merah & Terong & Pare & Kacang arab & Kacang hijau \\
\hline Napu & Tomat & Cabe & Terong & Kacang tanah & Kacang hijau \\
\hline Praibakul & Bawang putih & Bawang merah & Sawi putih & Tomat & Jagung \\
\hline Rambangaru & Jagung & Kacang tanah & Kacang hijau & Tomat & Cabe \\
\hline Wunga & Jagung & Kacang tanah & Pare & Padi & Terong \\
\hline \multicolumn{6}{|c|}{ Jenis tanaman tahunan } \\
\hline Kadahang & Sukun & Nangka & Mimba & Mangga & Jeruk \\
\hline Kalamba & Pinang & Mente & Kopi & Sukun & Kelapa \\
\hline Mbatapuhu & Sukun & Mente & Mangga & Jeruk & Kelapa \\
\hline Napu & Sukun & Nangka & Johar & Kedondong & Mangga \\
\hline Praibakul & Sukun & Pisang & Jeruk & Kelapa & Mente \\
\hline Rambangaru & Sukun & Pepaya & Pisang & Jeruk & Johar \\
\hline Wunga & Sukun & Jeruk & Kedondong & Pisang & Mangga \\
\hline \multicolumn{6}{|c|}{ Jenis tanaman untuk jangka panjang } \\
\hline Kadahang & Jati & Jati putih & Cendana & Mahoni & Injuwatu \\
\hline Kalamba & Cendana & Jati & Mahoni & Injuwatu & Tak tersedia \\
\hline Mbatapuhu & Mahoni & Jati & Cendana & Injuwatu & Sengon \\
\hline Napu & Jati & Kepuh & Mahoni & Marujawa & Injuwatu \\
\hline Praibakul & Cendana & Mahoni & Jati & Injuwatu & Jati putih \\
\hline Rambangaru & Jati & Injuwatu & Cendana & Mahoni & Tak tersedia \\
\hline Wunga & Cendana & Jati & Mahoni & Kayu putih & Injuwatu \\
\hline
\end{tabular}

Sumber: Data sekunder dari FGD dengan petani di 7 desa Kecamatan Haharu 


\subsubsection{Sekolah lapang agroforestri untuk rehabilitasi lahan}

Berdasarkan survei rumah tangga petani di Kecamatan Haharu, 90\% petani yang disurvei memilih sekolah lapang sebagai salah satu metode pelatihan yang akan diterapkan di Haharu. Hasil survei menunjukkan bahwa sebagian besar responden lebih suka metode penyuluhan yang berisi sesi praktis dan diskusi tatap muka. Konsep sekolah lapang yang menggunakan teknik pelatihan partisipatif untuk mencapai tujuan pembelajaran cocok dengan kebutuhan petani. Sekolah lapang agroforestri dapat menjadi pendekatan penyuluhan yang efektif untuk meningkatkan kapasitas petani dalam mengelola kebun dengan tujuan peningkatan dan keberlanjutan produktivitas (Martini et al., 2016).

Berdasarkan pengalaman pelaksanaan sekolah lapang agroforestri di Sulawesi Selatan dan Tenggara, Martini et al. (2016) menunjukkan bahwa 97\% peserta merasakan manfaat dari mengikuti sekolah lapang. Pengetahuan dan informasi baru yang terpercaya merupakan motivasi paling penting bagi petani untuk menghadiri sekolah lapang. Setelah satu tahun pelaksanaan sekolah lapang, 14\% responden merasakan manfaat berupa pendapatan tunai dengan menerapkan pengetahuan yang diperoleh. Jumlah uang yang diperoleh tergantung pada jenis pengetahuan yang dicobakan. Pemupukan dan pemangkasan adalah dua pengetahuan yang dapat menghasilkan manfaat uang tunai bagi petani dalam jangka pendek (dalam satu tahun). Evaluasi yang dilakukan menyimpulkan bahwa diperlukan sekurangnya pendampingan 1 tahun setelah selesainya sekolah lapang agar peserta dapat secara efektif menguji dan mengadaptasi pengetahuan baru yang mereka pelajari.

Untuk di Haharu, fokus sekolah lapang ditentukan berdasarkan kebutuhan penyuluhan agroforestri menurut para petani dan penyuluh. Sebagaimana dijelaskan di atas, topik pengelolaan jenis tanaman prioritas dapat dikombinasikan dengan teknologi untuk meningkatkan peran agroforestri dalam mendukung pengelolaan ternak, pengendalian kebakaran, dan peningkatan jumlah pohon di bentang alam Haharu.

\subsubsection{Kebun contoh agroforestri untuk rehabilitasi lahan}

Agroforestri merupakan pilihan cara pemanfaatan lahan yang dapat memberikan manfaat ekonomi maupun lingkungan bagi petani (de Foresta et al., 2000). Agroforestri dalam petak-petak lahan kecil dapat memberikan manfaat dari keragaman jenis pohon dan tanaman tahunan yang ada. Dengan menggabungkan jenis kayu yang memberikan penghasilan tahunan dengan jenis tanaman tahunan yang memberikan penghasilan jangka pendek, sistem agroforestri diharapkan dapat meningkatkan pencaharian pemilik lahan. Jika diterapkan untuk lahan yang jauh lebih luas (tingkat bentang alam), maka sistem agroforestri akan memberikan manfaat lingkungan yang lebih besar, seperti kesuburan tanah dan perbaikan iklim mikro, dua hal pokok yang mendukung keberhasilan program rehabilitasi lahan.

Biasanya, masing-masing petani mengembangkan sistem agroforestri mereka sendiri berdasarkan pengetahuan, pengalaman dan motivasi yang mereka miliki. Radandima (2001) mengindikasikan bahwa pengetahuan dan pengalaman petani merupakan dasar pengembangan program agroforestri di Sumba. Akan tetapi pengetahuan dan pengalaman masing-masing petani masih terbatas. Pengetahuan petani, terutama tentang konsep agroforestri, manajemen dan tumpangsari tanaman, pemilihan jenis 
tanaman prioritas, pengelolaan kesuburan tanah, dan perbanyakan bibit berkualitas, dapat ditingkatkan. Pembentukan demplot di setiap dusun akan menjadi wahana yang tepat untuk meningkatkan pengetahuan petani lewat penyuluhan agroforestri, dan hal ini sudah diterapkan di lokasi proyek ICRAF di Sulawesi, Indonesia (Martini et al., 2014).

Kebun contoh agroforestri perlu dirancang sesuai dengan kondisi lahan yang ada. Untuk Haharu, dua kondisi umum lahan dan pendekatan untuk masing-masing dirangkum di sini.

1) Jika lahan kritis dengan kanopi pohon kurang dari $25 \%$, maka pohon yang cocok ditanam adalah yang cepat tumbuh, toleran terhadap sinar matahari, dan juga memiliki nilai ekonomi seperti kelapa, nangka dan kemiri. Kehi (Lannea coromandelica) juga bisa ditanam sebagai pagar hidup untuk memberikan keteduhan dan penghalang ternak. Selain itu, kehi juga tahan api. Tanaman tahunan seperti kacang hijau, jagung, dan kacang tanah juga bisa ditanam di antara pohon-pohon untuk memberikan penghasilan jangka pendek bagi petani.

2) Jika kanopi pohon antara 25 hingga 50\%, tanaman yang toleran terhadap naungan seperti lada, kakao, kopi dan pala dapat ditanam di bawah pohon yang ada.

Diskusi dengan penyuluh di BP3K Haharu menghasilkan rekomendasi untuk mengembangkan demplot seperti yang dijelaskan dalam Tabel 11. Sebagian besar wilayah Haharu memiliki 25\% tutupan kanopi pohon, sehingga opsi kedua dapat diterapkan. Perencanaan, penilaian kondisi plot, dan pelaksanaan ujicoba harus dilakukan bersama petani yang nantinya merupakan pemanfaat dan pengadopsi teknologi. Partisipasi petani dalam perencanaan, pembentukan, dan pengelolaan demplot adalah suatu keharusan untuk memaksimalkan komitmen, pembelajaran, dan inovasi.

Tabel 11. Kebun contoh (demplot) yang direkomendasikan petugas penyuluhan.

\begin{tabular}{|c|c|c|}
\hline Prioritas & Lokasi & Fokus Demplot \\
\hline 1 & Kalamba & Tumpangsari turi-gamal-lamtoro-mahoni-kemiri \\
\hline 2 & $\begin{array}{l}\text { Rambangaru (Dusun } \\
\text { Hambuang) }\end{array}$ & $\begin{array}{l}\text { Tumpang sari kelapa-padi sawah; } \\
\text { Akuakultur dalam sistem agroforestri }\end{array}$ \\
\hline 3 & Praibakul & $\begin{array}{l}\text { Tumpangsari lamtoro-kelapa- jenis pohon lain; } \\
\text { Pengaturan jarak tanam - uji coba jenis tanaman; } \\
\text { Pengembangan sistem agroforestri mente }\end{array}$ \\
\hline 4 & Mbatapuhu & $\begin{array}{l}\text { Tumpangsari lamtoro-kelapa-jati putih; } \\
\text { Teknik agroforestri untuk mencegah kebakaran }\end{array}$ \\
\hline 5 & Kadahang (RT Ndara) & Tumpangsari mente-kelapa-lamtoro \\
\hline 6 & Napu (Dusun Prailangina) & Tumpang mahoni-jati putih-mente-lamtoro \\
\hline 7 & Wunga (Dusun Wunga Barat) & $\begin{array}{l}\text { Pengayaan demplot yang ada (dibuat oleh WVI) dengan } \\
\text { menanam jenis-jenis pohon tambahan lainnya }\end{array}$ \\
\hline
\end{tabular}

Sumber: FGD dengan staf penyuluh di Kecamatan Haharu

\section{KESIMPULAN}

Hasil penelitian ini menunjukkan bahwa hambatan-hambatan yang ditemui dalam upaya rehabilitasi lahan adalah keterbatasan sumber daya air, miskinnya kesuburan tanah, gangguan ternak, bahaya kebakaran, keterbatasan pendampingan untuk menjamin keberlanjutan program, serta terbatasnya 
persediaan bibit berkualitas. Berdasarkan temuan di atas, kebutuhan penyuluhan jangka pendek untuk rehabilitasi lahan di Kecamatan Haharu adalah (i) peningkatan pengetahuan petani tentang cara memperbaiki kesuburan tanah dengan menggunakan pupuk organik, dan (ii) pengembangan dan penerapan aturan penggembalaan dan pengelolaan kebakaran. Pelatihan dan berbagai upaya peningkatan kapasitas penyuluh tentang pembibitan pohon dan produksi pupuk organik akan memungkinkan penyuluh mampu membantu petani dalam merehabilitasi lahan melalui agroforestri.

Sekolah lapang agroforestri adalah pilihan utama pendekatan penyuluhan yang diminta petani untuk meningkatkan pengetahuan dan kemampuan mereka dalam mengelola kebun dan rehabilitasi lahan di Kecamatan Haharu. Dalam pelaksanaan sekolah lapang agroforestri, topik pengelolaan pohon prioritas dapat dikombinasikan dengan topik teknologi peningkatan peran agroforestri dalam membantu manajemen ternak, kontrol api, dan peningkatan jumlah pohon di wilayah yang dimaksud.

Terintegrasi dengan sekolah lapang agroforestri, kebun contoh agroforestri diharapkan dapat dibangun di setiap dusun, berfungsi sebagai media interaktif bagi petani, penyuluh, dan peneliti untuk belajar dan praktik agroforestri yang dapat membantu upaya rehabilitasi lahan di Kecamatan Haharu. Penyuluh dan petani perlu bekerja sama dan secara intensif memastikan partisipasi dan pembelajaran petani dalam proses perencanaan, pembentukan dan pengelolaan kebun contoh atau demplot.

Sistem agroforestri yang dapat dikembangkan dalam demplot adalah kombinasi jenis tanaman prioritas dan jenis tanaman yang menarik bagi petani. Saat ini, petani lebih tertarik dengan jenis tanaman baru yang mampu tumbuh subur dalam kondisi Haharu dan juga memberikan keuntungan ekonomi yang baik seperti kayu-kayuan, mente, dan sukun. Jenis kayu-kayuan ditanam untuk persiapan pendapatan jangka panjang, sementara mente, pinang dan sukun untuk pendapatan tahunan mulai 5-10 tahun setelah penanaman. Untuk jangka pendek (mingguan atau bulanan) petani memperoleh pendapatan dari kacang hijau, kacang tanah, bawang merah, bawang putih, tomat, dan jagung.

Secara ringkas, rekomendasi yang diberikan adalah sbb:

1. Peningkatan pengetahuan petani tentang perbaikan kesuburan tanah dengan penggunaan pupuk organik;

2. Pengembangan dan penerapan aturan penggembalaan dan pengelolaan kebakaran yang tepat;

3. Penyediaan pelatihan dan kegiatan untuk meningkatkan kapasitas penyuluh tentang pengembangan pembibitan pohon dan produksi pupuk organik;

4. Peningkatan upaya membantu petani melalui pengenalan, pengujian dan adopsi pohon dan jenis tanaman tahunan yang memberikan manfaat ekonomi;

5. Pemanfaatan pendekatan sekolah lapang agroforestri untuk meningkatkan kesadaran, pengetahuan dan pengalaman petani; dan

6. Pembuatan kebun contoh / demplot - direncanakan, dibangun, dan dikelola bersama petani atas dukungan tenaga penyuluh pemerintah - sebagai bagian terpadu dari pendekatan sekolah lapang agroforestri. 


\section{Referensi}

Badan Pusat Statistik (BPS). 2009. Kecamatan Haharu Dalam Angka tahun 2009. BPS Kecamatan Haharu.

Badan Pusat Statistik (BPS). 2010. Kecamatan Haharu Dalam Angka tahun 2010. BPS Kecamatan Haharu.

Badan Pusat Statistik (BPS). 2011. Kecamatan Haharu Dalam Angka tahun 2011. BPS Kecamatan Haharu.

Badan Pusat Statistik (BPS). 2012. Kecamatan Haharu Dalam Angka tahun 2012. BPS Kecamatan Haharu.

Badan Pusat Statistik (BPS). 2013. Kecamatan Haharu Dalam Angka tahun 2013. BPS Kecamatan Haharu.

Badan Pusat Statistik (BPS). 2014. Kecamatan Haharu Dalam Angka tahun 2014. BPS Kecamatan Haharu.

Badan Pusat Statistik (BPS). 2015. Kabupaten Sumba Timur Dalam Angka tahun 2015. BPS Kecamatan Haharu.

de Foresta, H., Kusworo A, Michon G, Djatmiko WA. 2000. KetikaKebunBerupaHutan Agroforest Khas Indonesia. World Agroforestry Centre (ICRAF). Bogor.

Hutabarat, S. 2006. Model Forest: Alternatif Pengelolaan Hutan di Nusa Tenggara Timur. Prosiding Sosialisasi Hasil-Hasil Penelitian Kehutanan. Pusat Litbang Hutan dan Konservasi Alam. Bogor.

Martini E, Saad U, Angreiny Y, Roshetko JM. 2014. Kebun Belajar Agroforestri: Konsep dan Pembelajaran dari Sulawesi Selatan dan Tenggara. Proseding Seminar Nasional Agroforestri ke-5, 21 Nov 2014, Ambon, Indonesia.

Martini E, Saad U, Angreiny Y, Roshetko JM, Gunawan H, Maulana HT, Suganda G, Dwipayana G, Erwin LO, Hadedi A. 2016. Agroforestry and Forestry in Sulawesi series: Evaluation of the Agroforestry Farmer Field Schools on agroforestry management in South and Southeast Sulawesi, Indonesia. Working paper 220. Bogor, Indonesia: World Agroforestry Centre (ICRAF) Southeast Asia Regional Program. 16p. DOI: 10.5716/WP16002.PDF.

Monk, K.A., Y. de Fretes and G. Reksodiharjo-Lilley. 1997. The ecology of Nusa Tenggara and Maluku. The ecology of Indonesia series, volume 5. Dalhousie University, Nova Scotia, Canada.

Njurumana GND. 2008. Rehabilitasi Lahan Kritis Berbasis Agrosylvopastur di Timor dan Sumba, Nusa Tenggara Timur. Info Hutan Vol V(2): 99-112.

Njurumana, GND, Prasetyo, BD. 2010. Lende Ura, Sebuah Inisiatif Masyarakat dalam Rehabilitasi Hutan dan Lahan di Sumba Barat Daya. Jurnal Analisis Kebijakan kehutanan Vol 7(2): 97-110.

Radandima, U. 2001. Pengembangan masyarakat dalam pengelolaan sumber daya alam melalui program wanatani: Pengalaman Yayasan Tananua Sumba. In: JM Roshetko, Mulawarman, WJ Santoso and I.N. Oka. Wanatani di Nusa Tenggara. Prosiding Lokakarya Wanatani Se-Nusa Tenggara (Agroforestry in Nusa Tenggara, Proceedings of a Workshop), 11-14 November 2001. Denpasar, Bali. International Centre for Research in Agroforestry (ICRAF) and Winrock International

Rinaudo, T. 2012. Natural Resources Advisor, World Vision Australia and pioneer of Farmer Managed Natural Regeneration in Niger in 1983. World Vision Australia. 
Roshetko JM and Mulawarman. 2002. Wanatani di Nusa Tenggara: Ringkasan hasil lokakarya (Agroforestry for Nusa Tenggara: A Summary of Workshop Outputs). In: JM Roshetko, Mulawarman, WJ Santoso and I.N. Oka. Wanatani di Nusa Tenggara. Prosiding Lokakarya Wanatani Se-Nusa Tenggara (Agroforestry in Nusa Tenggara, Proceedings of a Workshop), 11-14 November 2001. Denpasar, Bali. International Centre for Research in Agroforestry (ICRAF) and Winrock International.

Stubenvoll, S. 2000. Traditional Agroforestry and Ecological, Social, and Economic Sustaqinability on Small Tropical Islands: A dynamic land-use system and its potential for community-basd development in Tioor and Rhun, Central Maluku, Indonesia. Doctoral Dissertation. School of Architecture - Environment - Society, Technical University of Berlin. 


\section{Lampiran 1. Sketsa Desa Wunga, Kadahang dan Rambangaru}

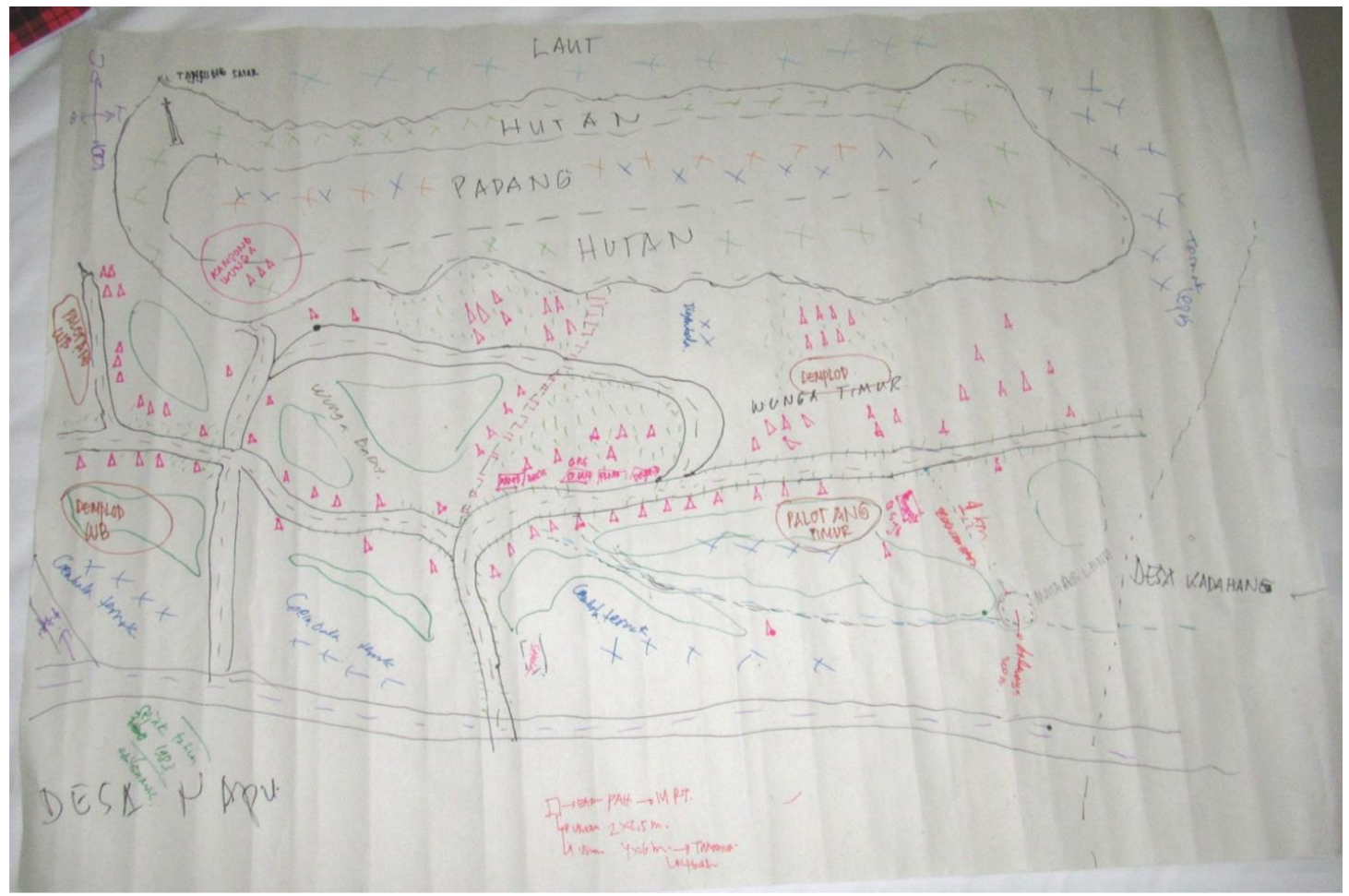

Gambar 6. Sketsa Desa Wunga, Kecamatan Haharu, Sumba Timur

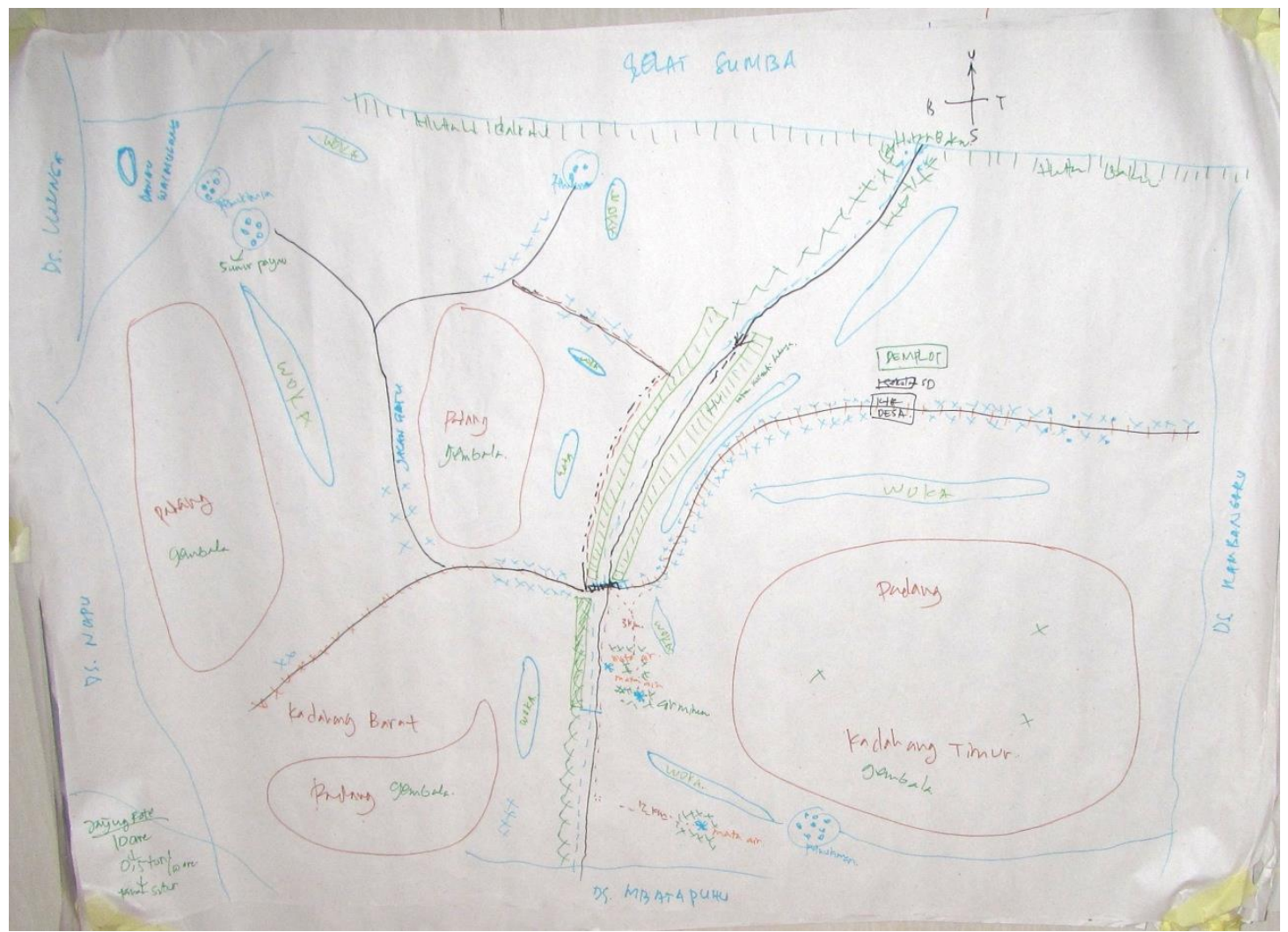

Gambar 7. Sketsa Desa Kadahang, Kecamatan Haharu, Sumba Timur 


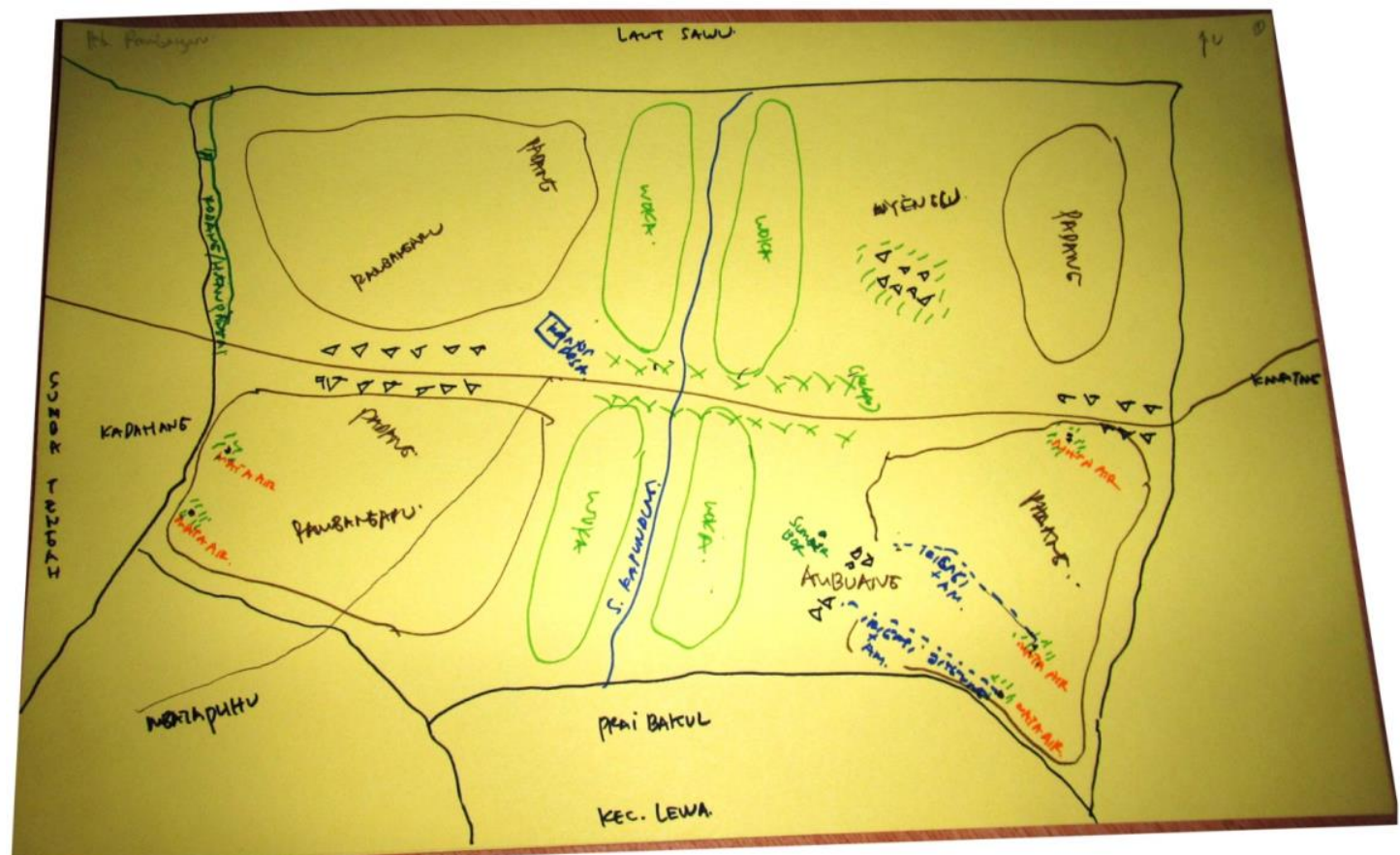

Gambar 8. Sketsa Desa Rambangaru, Kecamatan Haharu, Sumba Timur 



\section{WORKING PAPERS WITH DOIS}

\section{5}

1. Agroforestry in the drylands of eastern Africa: a call to action

2. Biodiversity conservation through agroforestry: managing tree species diversity within a network of community-based, nongovernmental, governmental and research organizations in western Kenya.

3. Invasion of prosopis juliflora and local livelihoods: Case study from the Lake Baringo area of Kenya

4. Leadership for change in farmers organizations: Training report: Ridar Hotel, Kampala, 29th March to 2nd April 2005.

5. Domestication des espèces agroforestières au Sahel : situation actuelle et perspectives

6. Relevé des données de biodiversité ligneuse: Manuel du projet biodiversité des parcs agroforestiers au Sahel

7. Improved land management in the Lake Victoria Basin: TransVic Project's draft report.

8. Livelihood capital, strategies and outcomes in the Taita hills of Kenya

9. Les espèces ligneuses et leurs usages: Les préférences des paysans dans le Cercle de Ségou, au Mali

10. La biodiversité des espèces ligneuses: Diversité arborée et unités de gestion du terroir dans le Cercle de Ségou, au Mali

\section{6}

11. Bird diversity and land use on the slopes of Mt. Kilimanjaro and the adjacent plains, Tanzania

12. Water, women and local social organization in the Western Kenya Highlands

13. Highlights of ongoing research of the World Agroforestry Centre in Indonesia

14. Prospects of adoption of tree-based systems in a rural landscape and its likely impacts on carbon stocks and farmers' welfare: The FALLOW Model Application in Muara Sungkai, Lampung, Sumatra, in a 'Clean Development Mechanism' context

15. Equipping integrated natural resource managers for healthy Agroforestry landscapes.

17. Agro-biodiversity and CGIAR tree and forest science: approaches and examples from Sumatra.

18. Improving land management in eastern and southern Africa: A review of policies.

19. Farm and household economic study of Kecamatan Nanggung, Kabupaten Bogor, Indonesia: A socioeconomic base line study of Agroforestry innovations and livelihood enhancement.

20. Lessons from eastern Africa's unsustainable charcoal business.

21. Evolution of RELMA's approaches to land management: Lessons from two decades of research and development in eastern and southern Africa

22. Participatory watershed management: Lessons from RELMA's work with farmers in eastern Africa.

23. Strengthening farmers' organizations: The experience of RELMA and ULAMP.

24. Promoting rainwater harvesting in eastern and southern Africa.

25. The role of livestock in integrated land management.

26. Status of carbon sequestration projects in Africa: Potential benefits and challenges to scaling up.

27. Social and Environmental Trade-Offs in Tree Species Selection: A Methodology for Identifying Niche Incompatibilities in Agroforestry [Appears as AHI Working Paper no. 9]

28. Managing tradeoffs in agroforestry: From conflict to collaboration in natural resource management. [Appears as AHI Working Paper no. 10]

29. Essai d'analyse de la prise en compte des systemes agroforestiers pa les legislations forestieres au Sahel: Cas du Burkina Faso, du Mali, du Niger et du Senegal.

30. Etat de la recherche agroforestière au Rwanda etude bibliographique, période 1987-2003 
31. Science and technological innovations for improving soil fertility and management in Africa: A report for NEPAD's Science and Technology Forum.

32. Compensation and rewards for environmental services.

33. Latin American regional workshop report compensation.

34. Asia regional workshop on compensation ecosystem services.

35. Report of African regional workshop on compensation ecosystem services.

36. Exploring the inter-linkages among and between compensation and rewards for ecosystem services CRES and human well-being

37. Criteria and indicators for environmental service compensation and reward mechanisms: realistic, voluntary, conditional and pro-poor

38. The conditions for effective mechanisms of compensation and rewards for environmental services.

39. Organization and governance for fostering Pro-Poor Compensation for Environmental Services.

40. How important are different types of compensation and reward mechanisms shaping poverty and ecosystem services across Africa, Asia \& Latin America over the Next two decades?

41. Risk mitigation in contract farming: The case of poultry, cotton, woodfuel and cereals in East Africa.

42. The RELMA savings and credit experiences: Sowing the seed of sustainability

43. Yatich J., Policy and institutional context for NRM in Kenya: Challenges and opportunities for Landcare.

44. Nina-Nina Adoung Nasional di So! Field test of rapid land tenure assessment (RATA) in the Batang Toru Watershed, North Sumatera.

45. Is Hutan Tanaman Rakyat a new paradigm in community based tree planting in Indonesia?

46. Socio-Economic aspects of brackish water aquaculture (Tambak) production in Nanggroe Aceh Darrusalam.

47. Farmer livelihoods in the humid forest and moist savannah zones of Cameroon.

48. Domestication, genre et vulnérabilité : Participation des femmes, des Jeunes et des catégories les plus pauvres à la domestication des arbres agroforestiers au Cameroun.

49. Land tenure and management in the districts around Mt Elgon: An assessment presented to the Mt Elgon ecosystem conservation programme.

50. The production and marketing of leaf meal from fodder shrubs in Tanga, Tanzania: A pro-poor enterprise for improving livestock productivity.

51. Buyers Perspective on Environmental Services (ES) and Commoditization as an approach to liberate ES markets in the Philippines.

52. Towards Towards community-driven conservation in southwest China: Reconciling state and local perceptions.

53. Biofuels in China: An Analysis of the Opportunities and Challenges of Jatropha curcas in Southwest China.

54. Jatropha curcas biodiesel production in Kenya: Economics and potential value chain development for smallholder farmers

55. Livelihoods and Forest Resources in Aceh and Nias for a Sustainable Forest Resource Management and Economic Progress

56. Agroforestry on the interface of Orangutan Conservation and Sustainable Livelihoods in Batang Toru, North Sumatra. 
57. Assessing Hydrological Situation of Kapuas Hulu Basin, Kapuas Hulu Regency, West Kalimantan.

58. Assessing the Hydrological Situation of Talau Watershed, Belu Regency, East Nusa Tenggara.

59. Kajian Kondisi Hidrologis DAS Talau, Kabupaten Belu, Nusa Tenggara Timur.

60. Kajian Kondisi Hidrologis DAS Kapuas Hulu, Kabupaten Kapuas Hulu, Kalimantan Barat.

61. Lessons learned from community capacity building activities to support agroforest as sustainable economic alternatives in Batang Toru orang utan habitat conservation program (Martini, Endri et al.)

62. Mainstreaming Climate Change in the Philippines.

63. A Conjoint Analysis of Farmer Preferences for Community Forestry Contracts in the Sumber Jaya Watershed, Indonesia.

64. The highlands: a shared water tower in a changing climate and changing Asia

65. Eco-Certification: Can It Deliver Conservation and Development in the Tropics.

66. Designing ecological and biodiversity sampling strategies. Towards mainstreaming climate change in grassland management.

67. Towards mainstreaming climate change in grassland management policies and practices on the Tibetan Plateau

68. An Assessment of the Potential for Carbon Finance in Rangelands

69 ECA Trade-offs Among Ecosystem Services in the Lake Victoria Basin.

69. The last remnants of mega biodiversity in West Java and Banten: an in-depth exploration of RaTA (Rapid Land Tenure Assessment) in Mount Halimun-Salak National Park Indonesia

70. Le business plan d'une petite entreprise rurale de production et de commercialisation des plants des arbres locaux. Cas de quatre pépinières rurales au Cameroun.

71. Les unités de transformation des produits forestiers non ligneux alimentaires au Cameroun. Diagnostic technique et stratégie de développement Honoré Tabuna et Ingratia Kayitavu.

72. Les exportateurs camerounais de safou (Dacryodes edulis) sur le marché sous régional et international. Profil, fonctionnement et stratégies de développement.

73. Impact of the Southeast Asian Network for Agroforestry Education (SEANAFE) on agroforestry education capacity.

74. Setting landscape conservation targets and promoting them through compatible land use in the Philippines.

75. Review of methods for researching multistrata systems.

76. Study on economical viability of Jatropha curcas L. plantations in Northern Tanzania assessing farmers' prospects via cost-benefit analysis

77. Cooperation in Agroforestry between Ministry of Forestry of Indonesia and International Center for Research in Agroforestry

78. "China's bioenergy future. an analysis through the Lens if Yunnan Province

79. Land tenure and agricultural productivity in Africa: A comparative analysis of the economics literature and recent policy strategies and reforms

80. Boundary organizations, objects and agents: linking knowledge with action in Agroforestry watersheds

81. Reducing emissions from deforestation and forest degradation (REDD) in Indonesia: options and challenges for fair and efficient payment distribution mechanisms 
82. Mainstreaming climate change into agricultural education: challenges and perspectives

83. Challenging conventional mindsets and disconnects in conservation: the emerging role of ecoagriculture in Kenya's landscape mosaics

84. Lesson learned RATA garut dan bengkunat: suatu upaya membedah kebijakan pelepasan kawasan hutan dan redistribusi tanah bekas kawasan hutan

85. The emergence of forest land redistribution in Indonesia

86. Commercial opportunities for fruit in Malawi

87. Status of fruit production processing and marketing in Malawi

88. Fraud in tree science

89. Trees on farm: analysis of global extent and geographical patterns of agroforestry

90. The springs of Nyando: water, social organization and livelihoods in Western Kenya

91. Building capacity toward region-wide curriculum and teaching materials development in agroforestry education in Southeast Asia

92. Overview of biomass energy technology in rural Yunnan (Chinese - English abstract)

93. A pro-growth pathway for reducing net GHG emissions in China

94. Analysis of local livelihoods from past to present in the central Kalimantan Ex-Mega Rice Project area

95. Constraints and options to enhancing production of high quality feeds in dairy production in Kenya, Uganda and Rwanda

2010

96. Agroforestry education in the Philippines: status report from the Southeast Asian Network for Agroforestry Education (SEANAFE)

97. Economic viability of Jatropha curcas L. plantations in Northern Tanzania- assessing farmers' prospects via cost-benefit analysis.

98. Hot spot of emission and confusion: land tenure insecurity, contested policies and competing claims in the central Kalimantan Ex-Mega Rice Project area

99. Agroforestry competences and human resources needs in the Philippines

100. CES/COS/CIS paradigms for compensation and rewards to enhance environmental Services

101. Case study approach to region-wide curriculum and teaching materials development in agroforestry education in Southeast Asia

102. Stewardship agreement to reduce emissions from deforestation and degradation (REDD): Lubuk Beringin's Hutan Desa as the first village forest in Indonesia

103. Landscape dynamics over time and space from ecological perspective

104. Komoditisasi atau koinvestasi jasa lingkungan: skema imbal jasa lingkungan program peduli sungai di DAS Way Besai, Lampung, Indonesia

105. Improving smallholders' rubber quality in Lubuk Beringin, Bungo district, Jambi province, Indonesia: an initial analysis of the financial and social benefits

106. Rapid Carbon Stock Appraisal (RACSA) in Kalahan, Nueva Vizcaya, Philippines

107. Tree domestication by ICRAF and partners in the Peruvian Amazon: lessons learned and future prospects in the domain of the Amazon Initiative eco-regional program

108. Memorias del Taller Nacional: "Iniciativas para Reducir la Deforestación en la region Andino Amazónica", 09 de Abril del 2010. Proyecto REALU Peru

109. Percepciones sobre la Equidad y Eficiencia en la cadena de valor de REDD en Perú -Reporte de Talleres en Ucayali, San Martín y Loreto, 2009. Proyecto REALU-Perú. 
110. Reducción de emisiones de todos los Usos del Suelo. Reporte del Proyecto REALU Perú Fase 1

111. Programa Alternativas a la Tumba-y-Quema (ASB) en el Perú. Informe Resumen y Síntesis de la Fase II. 2da. versión revisada

112. Estudio de las cadenas de abastecimiento de germoplasma forestal en la amazonía Boliviana

113. Biodiesel in the Amazon

114. Estudio de mercado de semillas forestales en la amazonía Colombiana

115. Estudio de las cadenas de abastecimiento de germoplasma forestal en Ecuador http://dx.doi.org10.5716/WP10340.PDF

116. How can systems thinking, social capital and social network analysis help programs achieve impact at scale?

117. Energy policies, forests and local communities in the Ucayali Region, Peruvian Amazon

118. NTFPs as a Source of Livelihood Diversification for Local Communities in the Batang Toru Orangutan Conservation Program

119. Studi Biodiversitas: Apakah agroforestry mampu mengkonservasi keanekaragaman hayati di DAS Konto?

120. Estimasi Karbon Tersimpan di Lahan-lahan Pertanian di DAS Konto, Jawa Timur

121. Implementasi Kaji Cepat Hidrologi (RHA) di Hulu DAS Brantas, Jawa Timur. http://dx.doi.org/10.5716/WP10338.PDF

122. Kaji Cepat Hidrologi di Daerah Aliran Sungai Krueng Peusangan, NAD,Sumatra http://dx.doi.org/10.5716/WP10337.PDF

123. A Study of Rapid Hydrological Appraisal in the Krueng Peusangan Watershed, NAD, Sumatra. http://dx.doi.org/10.5716/WP10339.PDF

2011

124. An Assessment of farm timber value chains in Mt Kenya area, Kenya

125. A Comparative financial analysis of current land use systems and implications for the adoption of improved agroforestry in the East Usambaras, Tanzania

126. Agricultural monitoring and evaluation systems

127. Challenges and opportunities for collaborative landscape governance in the East Usambara Mountains, Tanzania

128. Transforming Knowledge to Enhance Integrated Natural Resource Management Research, Development and Advocacy in the Highlands of Eastern Africa http://dx.doi.org/10.5716/WP11084.PDF

129. Carbon-forestry projects in the Philippines: potential and challenges The Mt Kitanglad Range forestcarbon development http://dx.doi.org10.5716/WP11054.PDF

130. Carbon forestry projects in the Philippines: potential and challenges. The Arakan Forest Corridor forest-carbon project. http://dx.doi.org10.5716/WP11055.PDF

131. Carbon-forestry projects in the Philippines: potential and challenges. The Laguna Lake Development Authority's forest-carbon development project. http://dx.doi.org/10.5716/WP11056.PDF

132. Carbon-forestry projects in the Philippines: potential and challenges. The Quirino forest-carbon development project in Sierra Madre Biodiversity Corridor http://dx.doi.org10.5716/WP11057.PDF

133. Carbon-forestry projects in the Philippines: potential and challenges. The Ikalahan Ancestral Domain forest-carbon development http://dx.doi.org10.5716/WP11058.PDF

134. The Importance of Local Traditional Institutions in the Management of Natural Resources in the Highlands of Eastern Africa. http://dx.doi.org/10.5716/WP11085.PDF 
135. Socio-economic assessment of irrigation pilot projects in Rwanda. http://dx.doi.org/10.5716/WP11086.PDF

136. Performance of three rambutan varieties (Nephelium lappaceum L.) on various nursery media. http://dx.doi.org/10.5716/WP11232.PDF

137. Climate change adaptation and social protection in agroforestry systems: enhancing adaptive capacity and minimizing risk of drought in Zambia and Honduras http://dx.doi.org/10.5716/WP11269.PDF

138. Does value chain development contribute to rural poverty reduction? Evidence of asset building by smallholder coffee producers in Nicaragua http://dx.doi.org/10.5716/WP11271.PDF

139. Potential for biofuel feedstock in Kenya. http://dx.doi.org/10.5716/WP11272.PDF

140. Impact of fertilizer trees on maize production and food security in six districts of Malawi. http://dx.doi.org/10.5716/WP11281.PDF

\section{2}

141. Fortalecimiento de capacidades para la gestión del Santuario Nacional Pampa Hermosa:

Construyendo las bases para un manejo adaptativo para el desarrollo local. Memorias del Proyecto. http://dx.doi.org/10.5716/WP12005.PDF

142. Understanding rural institutional strengthening: A cross-level policy and institutional framework for sustainable development in Kenya http://dx.doi.org/10.5716/WP12012.PDF

143. Climate change vulnerability of agroforestry http://dx.doi.org/10.5716/WP16722.PDF

144. Rapid assesment of the inner Niger delta of Mali http://dx.doi.org/10.5716/WP12021.PDF

145. Designing an incentive program to reduce on-farm deforestationin the East Usambara Mountains, Tanzania http://dx.doi.org/10.5716/WP12048.PDF

146. Extent of adoption of conservation agriculture and agroforestry in Africa: the case of Tanzania, Kenya, Ghana, and Zambia http://dx.doi.org/10.5716/WP12049.PDF

147. Policy incentives for scaling up conservation agriculture with trees in Africa: the case of Tanzania, Kenya, Ghana and Zambia http://dx.doi.org/10.5716/WP12050.PDF

148. Commoditized or co-invested environmental services? Rewards for environmental services scheme: River Care program Way Besai watershed, Lampung, Indonesia. http://dx.doi.org/10.5716/WP12051.PDF

149. Assessment of the headwaters of the Blue Nile in Ethiopia. http://dx.doi.org/10.5716/WP12160.PDF

150. Assessment of the uThukela Watershed, Kwazaulu. http://dx.doi.org/10.5716/WP12161.PDF

151. Assessment of the Oum Zessar Watershed of Tunisia. http://dx.doi.org/10.5716/WP12162.PDF

152. Assessment of the Ruwenzori Mountains in Uganda. http://dx.doi.org/10.5716/WP12163.PDF

153. History of agroforestry research and development in Viet Nam. Analysis of research opportunities and gaps. http://dx.doi.org/10.5716/WP12052.PDF

154. REDD+ in Indonesia: a Historical Perspective. http://dx.doi.org/10.5716/WP12053.PDF

155. Agroforestry and Forestry in Sulawesi series: Livelihood strategies and land use system dynamics in South Sulawesi http://dx.doi.org/10.5716/WP12054.PDF

156. Agroforestry and Forestry in Sulawesi series: Livelihood strategies and land use system dynamics in Southeast Sulawesi. http://dx.doi.org/10.5716/WP12055.PDF

157. Agroforestry and Forestry in Sulawesi series: Profitability and land-use systems in South and Southeast Sulawesi. http://dx.doi.org/10.5716/WP12056.PDF

158. Agroforestry and Forestry in Sulawesi series: Gender, livelihoods and land in South and Southeast Sulawesi http://dx.doi.org/10.5716/WP12057.PDF 
159. Agroforestry and Forestry in Sulawesi series: Agroforestry extension needs at the community level in AgFor project sites in South and Southeast Sulawesi, Indonesia. http://dx.doi.org/10.5716/WP12058.PDF

160. Agroforestry and Forestry in Sulawesi series: Rapid market appraisal of agricultural, plantation and forestry commodities in South and Southeast Sulawesi. http://dx.doi.org/10.5716/WP12059.PDF

\section{3}

161. Diagnosis of farming systems in the Agroforestry for Livelihoods of Smallholder farmers in Northwestern Viet Nam project http://dx.doi.org/10.5716/WP13033.PDF

162. Ecosystem vulnerability to climate change: a literature review. http://dx.doi.org/10.5716/WP13034.PDF

163. Local capacity for implementing payments for environmental services schemes: lessons from the RUPES project in northeastern Viet Nam http://dx.doi.org/10.5716/WP13046.PDF

164. Seri Agroforestri dan Kehutanan di Sulawesi: Agroforestry dan Kehutanan di Sulawesi: Strategi mata pencaharian dan dinamika sistem penggunaan lahan di Sulawesi Selatan http://dx.doi.org/10.5716/WP13040.PDF

165. Seri Agroforestri dan Kehutanan di Sulawesi: Mata pencaharian dan dinamika sistem penggunaan lahan di Sulawesi Tenggara http://dx.doi.org/10.5716/WP13041.PDF

166. Seri Agroforestri dan Kehutanan di Sulawesi: Profitabilitas sistem penggunaan lahan di Sulawesi Selatan dan Sulawesi Tenggara http://dx.doi.org/10.5716/WP13042.PDF

167. Seri Agroforestri dan Kehutanan di Sulawesi: Gender, mata pencarian dan lahan di Sulawesi Selatan dan Sulawesi Tenggara http://dx.doi.org/10.5716/WP13043.PDF

168. Seri Agroforestri dan Kehutanan di Sulawesi: Kebutuhan penyuluhan agroforestri pada tingkat masyarakat di lokasi proyek AgFor di Sulawesi Selatan dan Tenggara, Indonesia. http://dx.doi.org/10.5716/WP13044.PDF

169. Seri Agroforestri dan Kehutanan di Sulawesi: Laporan hasil penilaian cepat untuk komoditas pertanian, perkebunan dan kehutanan di Sulawesi Selatan dan Tenggara http://dx.doi.org/10.5716/WP13045.PDF

170. Agroforestry, food and nutritional security http://dx.doi.org/10.5716/WP13054.PDF

171. Stakeholder Preferences over Rewards for Ecosystem Services: Implications for a REDD+ Benefit Distribution System in Viet Nam http://dx.doi.org/10.5716/WP13057.PDF

172. Payments for ecosystem services schemes: project-level insights on benefits for ecosystems and the rural poor http://dx.doi.org/10.5716/WP13001.PDF

173. Good practices for smallholder teak plantations: keys to success http://dx.doi.org/10.5716/WP13246.PDF

174. Market analysis of selected agroforestry products in the Vision for Change Project intervention Zone, Côte d'Ivoire http://dx.doi.org/10.5716/WP13249.PDF

175. Rattan futures in Katingan: why do smallholders abandon or keep their gardens in Indonesia's 'rattan district'? http://dx.doi.org/10.5716/WP13251.PDF

176. Management along a gradient: the case of Southeast Sulawesi's cacao production landscapes http://dx.doi.org/10.5716/WP13265.PDF

177. Are trees buffering ecosystems and livelihoods in agricultural landscapes of the Lower Mekong Basin? Consequences for climate-change adaptation. http://dx.doi.org/10.5716/WP14047.PDF 
178. Agroforestry, livestock, fodder production and climate change adaptation and mitigation in East Africa: issues and options. http://dx.doi.org/10.5716/WP14050.PDF

179. Trees on farms: an update and reanalysis of agroforestry's global extent and socio-ecological characteristics. http://dx.doi.org/10.5716/WP14064.PDF

180. Beyond reforestation: an assessment of Vietnam's REDD+ readiness. http://dx.doi.org/10.5716/WP14097.PDF

181. Farmer-to-farmer extension in Kenya: the perspectives of organizations using the approach. http://dx.doi.org/10.5716/WP14380.PDF

182. Farmer-to-farmer extension in Cameroon: a survey of extension organizations. http://dx.doi.org/10.5716/WP14383.PDF

183. Farmer-to-farmer extension approach in Malawi: a survey of organizations: a survey of organizations http://dx.doi.org/10.5716/WP14391.PDF

184. Seri Agroforestri dan Kehutanan di Sulawesi: Kuantifikasi jasa lingkungan air dan karbon pola agroforestri pada hutan rakyat di wilayah sungai Jeneberang

185. Options for Climate-Smart Agriculture at Kaptumo Site in Kenyahttp://dx.doi.org/10.5716/WP14394.PDF

\section{5}

186. Agroforestry for Landscape Restoration and Livelihood Development in Central Asia http://dx.doi.org/10.5716/WP14143.PDF

187. "Projected Climate Change and Impact on Bioclimatic Conditions in the Central and South-Central Asia Region" http://dx.doi.org/10.5716/WP14144.PDF

188. Land Cover Changes, Forest Loss and Degradation in Kutai Barat, Indonesia. http://dx.doi.org/10.5716/WP14145.PDF

189. The Farmer-to-Farmer Extension Approach in Malawi: A Survey of Lead Farmers. http://dx.doi.org/10.5716/WP14152.PDF

190. Evaluating indicators of land degradation and targeting agroforestry interventions in smallholder farming systems in Ethiopia. http://dx.doi.org/10.5716/WP14252.PDF

191. Land health surveillance for identifying land constraints and targeting land management options in smallholder farming systems in Western Cameroon

192. Land health surveillance in four agroecologies in Malawi

193. Cocoa Land Health Surveillance: an evidence-based approach to sustainable management of cocoa landscapes in the Nawa region, South-West Côte d'Ivoire http://dx.doi.org/10.5716/WP14255.PDF

194. Situational analysis report: Xishuangbanna autonomous Dai Prefecture, Yunnan Province, China. http://dx.doi.org/10.5716/WP14255.PDF

195. Farmer-to-farmer extension: a survey of lead farmers in Cameroon. http://dx.doi.org/10.5716/WP15009.PDF

196. From transition fuel to viable energy source Improving sustainability in the sub-Saharan charcoal sector http://dx.doi.org/10.5716/WP15011.PDF

197. Mobilizing Hybrid Knowledge for More Effective Water Governance in the Asian Highlands http://dx.doi.org/10.5716/WP15012.PDF

198. Water Governance in the Asian Highlands http://dx.doi.org/10.5716/WP15013.PDF

199. Assessing the Effectiveness of the Volunteer Farmer Trainer Approach in Dissemination of Livestock Feed Technologies in Kenya vis-à-vis other Information Sources http://dx.doi.org/10.5716/WP15022.PDF

200. The rooted pedon in a dynamic multifunctional landscape: Soil science at the World Agroforestry Centre http://dx.doi.org/10.5716/WP15023.PDF 
201. Characterising agro-ecological zones with local knowledge. Case study: Huong Khe district, Ha Tinh, Viet Nam http://dx.doi.org/10.5716/WP15050.PDF

202. Looking back to look ahead: Insight into the effectiveness and efficiency of selected advisory approaches in the dissemination of agricultural technologies indicative of Conservation Agriculture with Trees in Machakos County, Kenya. http://dx.doi.org/10.5716/WP15065.PDF

203. Pro-poor Biocarbon Projects in Eastern Africa Economic and Institutional Lessons. http://dx.doi.org/10.5716/WP15022.PDF

204. Projected climate change impacts on climatic suitability and geographical distribution of banana and coffee plantations in Nepal. http://dx.doi.org/10.5716/WP15294.PDF

205. Agroforestry and Forestry in Sulawesi series: Smallholders' coffee production and marketing in Indonesia. A case study of two villages in South Sulawesi Province. http://dx.doi.org/10.5716/WP15690.PDF

206. Mobile phone ownership and use of short message service by farmer trainers: a case study of Olkalou and Kaptumo in Kenya http://dx.doi.org/10.5716/WP15691.PDF

207. Associating multivariate climatic descriptors with cereal yields: a case study of Southern Burkina Faso http://dx.doi.org/10.5716/WP15273.PDF

208. Preferences and adoption of livestock feed practices among farmers in dairy management groups in Kenya http://dx.doi.org/10.5716/WP15675.PDF

209. Scaling up climate-smart agriculture: lessons learned from South Asia and pathways for success http://dx.doi.org/10.5716/WP15720.PDF

210. Agroforestry and Forestry in Sulawesi series: Local perceptions of forest ecosystem services and collaborative formulation of reward mechanisms in South and Southeast Sulawesi http://dx.doi.org/10.5716/WP15721.PDF

211. Potential and challenges in implementing the co-investment of ecosystem services scheme in Buol District, Indonesia. http://dx.doi.org/10.5716/WP15722.PDF

212. Tree diversity and its utilization by the local community in Buol District, Indonesia http://dx.doi.org/10.5716/WP15723.PDF

213 Vulnerability of smallholder farmers and their preferences on farming practices in Buol District, Indonesia http://dx.doi.org/10.5716/WP15724.PDF

214. Dynamics of Land Use/Cover Change and Carbon Emission in Buol District, Indonesia http://dx.doi.org/10.5716/WP15725.PDF

215. Gender perspective in smallholder farming practices in Lantapan, Phillippines. http://dx.doi.org/10.5716/WP15726.PDF

216. Vulnerability of smallholder farmers in Lantapan, Bukidnon. http://dx.doi.org/10.5716/WP15727.PDF

217. Vulnerability and adaptive capacity of smallholders in Ho Ho sub-watershed, north-central Viet Nam http://dx.doi.org/10.5716/WP15728.PDF

218. Local knowledge on the role of trees to enhance livelihoods and ecosystem services in Ho Ho Subwatershed, north-central Viet Nam http://dx.doi.org/10.5716/WP15729.PDF

219. Landuse/cover change in Ho Ho Sub-watershed, north-central Viet Nam. http://dx.doi.org/10.5716/WP15730.PDF

\section{6}

220. Agroforestry and Forestry in Sulawesi series: Evaluation of the Agroforestry Farmer Field Schools on agroforestry management in South and Southeast Sulawesi, Indonesia. http://dx.doi.org/10.5716/WP16002.PDF

221 Farmer-to-farmer extension of livestock feed technologies in Rwanda: A survey of volunteer farmer trainers and organizations. http://dx.doi.org/10.5716/WP16005.PDF 
222 Projected Climate Change Impact on Hydrology, Bioclimatic Conditions, and Terrestrial Ecosystems in the Asian Highlands http://dx.doi.org/10.5716/WP16006.PDF

223 Adoption of Agroforestry and its impact on household food security among farmers in Malawi http://dx.doi.org/10.5716/WP16013.PDF

224 Agroforestry and Forestry in Sulawesi series: Information channels for disseminating innovative agroforestry practices to villages in Southern Sulawesi, Indonesia http://dx.doi.org/10.5716/WP16034.PDF

225 Agroforestry and Forestry in Sulawesi series: Unravelling rural migration networks.Land-tenure arrangements among Bugis migrant communities in Southeast Sulawesi. http://dx.doi.org/10.5716/WP16035.PDF

226 Agroforestry and Forestry in Sulawesi series: Women's participation in agroforestry: more benefit or burden? A gendered analysis of Gorontalo Province. http://dx.doi.org/10.5716/WP16036.PDF

227 Kajian Kelayakan dan Pengembangan Desain Teknis Rehabilitasi Pesisir di Sulawesi Tengah. http://dx.doi.org/10.5716/WP16037.PDF

228. Selection of son tra clones in North West Vietnam. http://dx.doi.org/10.5716/WP16038.PDF

229. Growth and fruit yield of seedlings, cuttings and grafts from selected son tra trees in Northwest Vietnam http://dx.doi.org/10.5716/WP16046.PDF

230. Gender-Focused Analysis of Poverty and Vulnerability in Yunnan, China. http://dx.doi.org/10.5716/WP16071.PDF

231. Kebutuhan Penyuluhan Agroforestri untuk Rehabilitasi Lahan di Sumba Timur, Nusa Tenggara Timur, Indonesia.http://dx.doi.org/10.5716/WP16077.PDF 

The World Agroforestry Centre is an autonomous, non-profit research organization whose vision is a rural transformation in the developing world as smallholder households increase their use of trees in agricultural landscapes to improve food security, nutrition, income, health, shelter, social cohesion, energy resources and environmental sustainability. The Centre generates science-based knowledge about the diverse roles that trees play in agricultural landscapes, and uses its research to advance policies and practices, and their implementation that benefit the poor and the environment. It aims to ensure that all this is achieved by enhancing the quality of its science work, increasing operational efficiency, building and maintaining strong partnerships, accelerating the use and impact of its research, and promoting greater cohesion, interdependence and alignment within the organization.

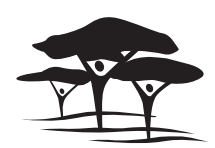

United Nations Avenue, Gigiri • PO Box 30677 • Nairobi, $00100 \cdot$ Kenya Telephone: +254 207224000 or via USA +1 6508336645 Fax: +254207224001 or via USA +16508336646 Email: worldagroforestry@cgiar.org•www.worldagroforestry.org

Southeast Asia Regional Program • Sindang Barang • Bogor 16680 PO Box $161 \cdot$ Bogor $16001 \cdot$ Indonesia

Telephone: +62 2518625415 • Fax: +62 2518625416 